\title{
Approaches towards practical adaptive management options for selected water-related sectors in South Africa in a context of climate change
}

\author{
Roland E Schulze* \\ School of Bioresources Engineering and Environmental Hydrology, University of KwaZulu-Natal, Pietermaritzburg, South Africa
}

\begin{abstract}
As a point of departure, the South African water-related sector is placed within the broader climate change context. Following on brief explanations of the terms adaptation, adaptive management and adaptive capacity, a summary of recent (2011) findings on projections of climate change effects on hydrological responses over South Africa is presented as the scientific cornerstone to practical adaptive management options. These options are based on the identification of major categories and subcategories in which adaptive capacity can be enhanced, the identification of 17 sectors within the broader South African water-related community which are likely to be impacted by climate change and the identification of the range of foreseen changes that these various sectors are likely to have to cope with, and adapt to, as a consequence of projected changes in climate drivers and hydrological responses. Five sectors are then selected for detailed case studies on adaptive management options, viz. national water planners, municipalities, rain-fed (dryland) agriculture, the insurance industry and aquatic ecosystems. The paper concludes by stressing the importance of adaptation to climate change and briefly outlines further plans of action in this field.
\end{abstract}

Keywords: climate change, South Africa, water sector, adaptation options

\section{Introduction}

\section{The climate change context and the South African water-related sector}

An overwhelming body of evidence, contained in thousands of scientific papers and summarised in a series of seminal reports emanating from the International Panel on Climate Change (most recently, IPCC, 2007), has been presented for increases in anthropogenically induced greenhouse gas emissions, often expressed through increases in atmospheric $\mathrm{CO}_{2}$ concentrations. Linked to these increases are observed increases in global temperatures and sea levels and, associated with a more energised atmosphere, are observations of changing rainfall patterns. Changes in patterns of climate variables since the 1950s have already been detected over South Africa, for example, by Kruger and Shongwe (2004), Hewitson et al. (2005), Warburton et al. (2005), Warburton and Schulze (2005), Kruger (2006) and in a wide range of ongoing climate-detection studies reported in South Africa's Second National Communication under the United Nations Framework Convention on Climate Change (DEA, 2010).

With further projected changes in global climates into the future, changes in the South African water sector will be inevitable, especially since the regional climate in South Africa is dependent on global climate, both today and in the future. In the light of uncertainties in future population, economic,

This paper was originally presented at the Water Research Commission 40-Year Celebration Conference, Kempton Park, 31 August - 1 September 2011.

* To whom all correspondence should be addressed.

III +27 33 260-5489; fax: +27 33 260-5818;

e-mail: schulzer@ukzn.ac.za technological and land use-trends, and hence greenhouse gas emissions and the success (or not) of mitigation strategies (e.g. the Kyoto Protocol), no one knows exactly how the future global climate will develop (Nakićenović et al., 2000). Hence it is not known with certainty what the resultant consequences in South Africa will be for, among others, the water sector. However, South Africa, with its geographical location, lies in one of the regions of the world that has been identified by the IPCC (2007) as being amongst the most vulnerable to climate variability and change.

Impacts of a changing climate on the South African water sector are therefore likely to be considerable. Already, South Africa's water resources are subjected to the high risk hydroclimatic environments in which they have to operate, with on average only $8 \%$ to $9 \%$ of the county's relatively low annual rainfall (which is only $\sim 56 \%$ of the world mean) being converted to streamflow (Whitmore, 1971; DWAF, 2004), its high variability in runoff both over space and over time and its high atmospheric evaporative demand (Schulze, 2008). These factors are key constraints to the country's continued economic development and the sustainable livelihoods of its people.

Figure 1 shows that the management of water resources in South Africa is already challenging from a supply/demand perspective under existing and future conditions, from a more ecological (i.e. river basin) perspective of in-stream and off-stream considerations as well as from an organisational perspective at both institutional and individual levels. Of importance are the following further aspects:

- Water is arguably the primary medium through which early (and subsequent) climate change impacts will be felt by people, ecosystems and economies

- A large proportion of South Africa's population is impoverished (thus rendering them particularly vulnerable to impacts of climate change) 


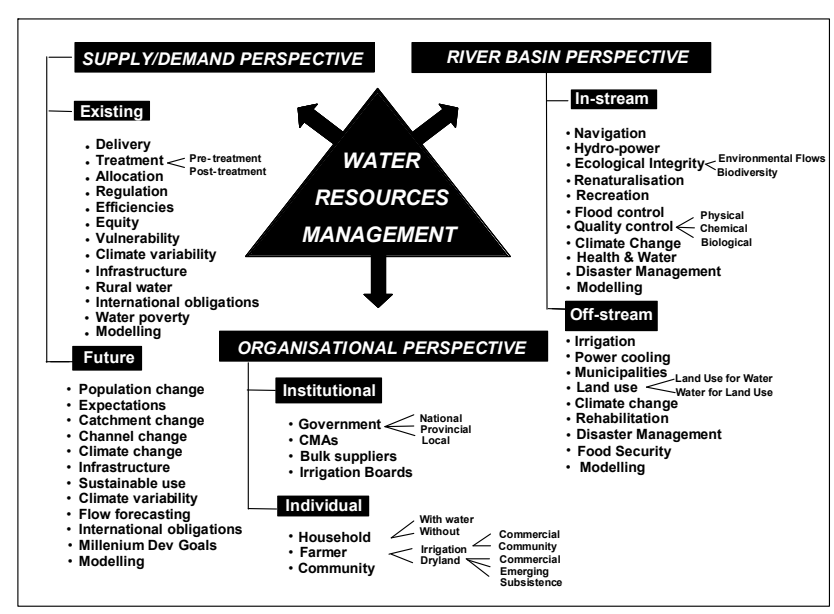

Figure 1

The interlinked nature of water resource management in South Africa (Schulze, 2005a)

- Many of the fragile ecosystems in South Africa (both terrestrial and aquatic) are implicitly or explicitly water dependent (cf. Fig. 2).

It has therefore become necessary to gain a more comprehensive understanding than we have had up until now of the physical drivers and the hydrological responses of climate change on the landscape component of catchments, the channel component of the catchment and the transitional components of the hydrological system such as wetlands, riparian zones and estuaries, each with their key issues with respect to climate change (Fig. 2). This has been largely achieved through the hydro-climatic modelling efforts described in the biophysical component of the report (Schulze, 2011) on a recently completed project funded by the Water Research Commission (Project No. K5/1843), titled
'An Evaluation of the Sensitivity of Socio-Economic Activities to Climate Change in Climatically Divergent South African Catchments'.

\section{Objectives of this paper}

Given the above background on climate change and the water sector and, furthermore, the fact that any changes in rainfall patterns are amplified through the hydrological system and that hydraulic structures such as dams spillways or urban stormwater drainage systems are constructed with a design life of 50 years to 100 years (i.e. well into the era of projected climate change), as well as being expensive and essentially irreversible once in place, this paper is aimed at outlining approaches towards practical adaptive management options for selected water-related sectors in South Africa in a context of climate change. This is done by identifying:

- The major categories in which adaptive capacity can be enhanced

- Sectors within the broader water-related community in South Africa which are likely to be impacted

- The range of foreseen changes that the various sectors would have to be coping with, and adapting to, in regard to projected changes in the drivers of the hydrological system (e.g. in temperature, evaporation and/or rainfall characteristics) and changes in the responses of the hydrological system (e.g. in streamflow, or droughts, or irrigation requirements).

As points of departure related to the main aim of the paper, an explanation is first given on what is understood by adaptation as well as adaptive management and adaptive capacity. A summary of the most recent findings on climate change impacts on the South African water scene then provides the scientific backdrop to adaptive management options. Thereafter, practical approaches towards adaptive management options are presented.

Figure 2
Hydrological
model
requirements
under conditions
of climate change
(Schulze, 2005b)

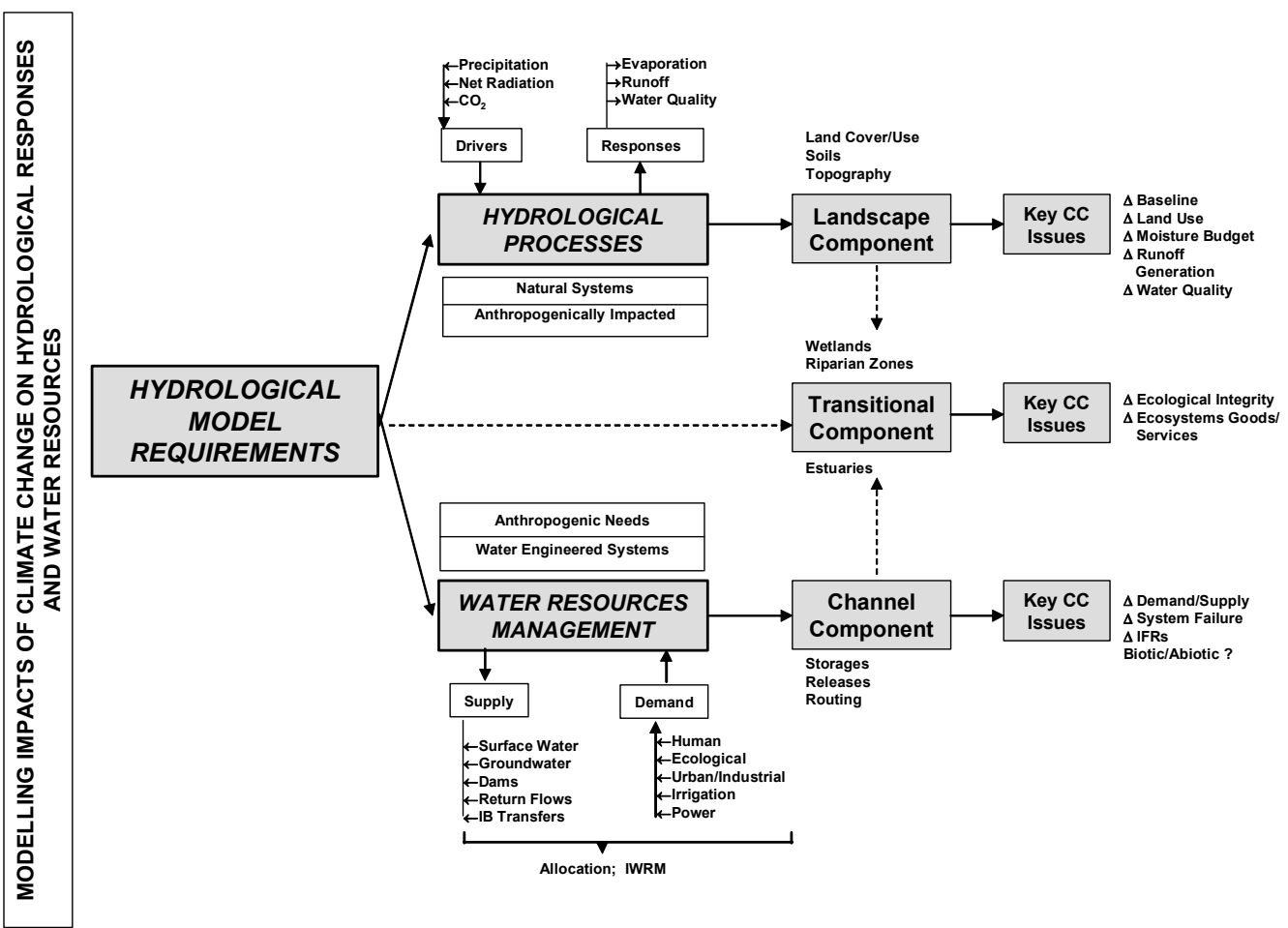




\section{On concepts of adaptation, adaptive management and adaptive capacity}

The core theme of this paper is on adaptation and related concepts. Adaptation, from various sources within the IPCC (2007) literature, may be defined as actual adjustments in natural or human systems, or changes in decision environments, in response to actual or expected climatic stimuli or their effects, which could moderate harm and which might therefore ultimately enhance resilience or reduce vulnerability to observed or expected changes in climate, or exploit beneficial opportunities. The UNFCCC (2007) in some ways expands on the above, with adaptation being defined as 'a process through which societies make themselves better able to cope with an uncertain future. Adapting to climate change entails taking the right measures to reduce the negative effects of climate change (or exploit the positive ones) by making the appropriate adjustments and changes'.

Various types of adaptation can be distinguished, including anticipatory and reactive adaptation, private and public adaptation, and autonomous and planned adaptation (IPCC, 2007):

- Anticipatory adaptation is adaptation that takes place before impacts of climate change are observed. It is also referred to as proactive adaptation.

- Autonomous adaptation is adaptation that does not constitute a conscious response to climatic stimuli, but is triggered by ecological changes in natural systems and by market or welfare changes in human systems. This is also referred to as spontaneous adaptation.

- Planned adaptation is the result of a deliberate policy decision, based on an awareness that conditions have changed or are about to change and that action is required to return to, maintain, or achieve a desired state, while

- Private adaptation is initiated and implemented by individuals, households or private companies, usually in the actor's rational self-interest.

- Public adaptation is initiated and implemented by governments at all levels and is usually directed at collective needs.

- Reactive adaptation takes place after impacts of climate change have been observed. Reactive approaches are seen as inefficient and not always successful (IPCC, 2007).

As alluded to above, the drivers of adaptation differ as a function of the administrative setting. According to Theesfeld et al. (2011), adaptation at 'higher' levels (e.g. central government) tends to be deliberate and is driven by planned institutional adaptation, meeting in-country environmental policy targets, meeting international obligations and commitments (e.g. to the UNFCCC) and co-ordination across agencies which have climate change agendas. Adaptation at higher levels is, as a rule, thus intentional, anticipatory, pro-active, long-term and strategic.

At 'lower' levels (e.g. local government) adaptation tends to be autonomous and is driven by hydro-climatic drivers such as experiences of floods and droughts, with rules and procedures often put in place to facilitate technical coping solutions, with a mix of climate and non-climate factors and with bottom-up initiatives by NGOs and/or local media, plus blending indigenous experience/knowledge with anticipated change. Adaptation at lower levels thus tends to be more spontaneous, reactive, shortterm and practical.

Adaptation practices can be differentiated along several dimensions (IPCC, 2007). These include differentiating, for example, by:
- Spatial scale (local, regional, national)

- Sector (water resources, agriculture, tourism, public health, and so on)

- Type of action (physical, technological, investment, regulatory, market)

- Actor (national or local government, international donors, private sector, NGOs, local communities and individuals)

- Climatic zone (dryland, floodplains, mountains, etc.)

- Baseline income / development level of the systems in which they are implemented (least-developed countries, middle income countries, and developed countries)

- Some combination of the above and other categories.

From a temporal perspective, adaptation to climate risks can be viewed at 3 levels, viz. responses to current variability (which also reflect learning from past adaptations to historical climatic events), observed medium- and long-term trends in climate and anticipatory planning in response to model-based scenarios of projected climate change. The responses across these 3 levels are often intertwined and, indeed, might form a continuum. In light of all of the above, adaptive management, in the context of this paper, is focused on operational aspects of water supply, demand, allocation, security and safety into a future which is hydrologically non-stationary. However, adaptive management does not deal exclusively with operational issues since any projected changes in climate may manifest themselves through other, non-hydrological responses. Imbedded in the concept of adaptive management is that of adaptive governance, which refers to the making of rules (e.g. assigning water rights, handling trade-offs, centralised vs. decentralised water management) and the implementation of those rules (IPCC, 2007).

Central to the theme of this paper is the capacity to adapt. According to Brooks and Adger (2005) and the IPCC (2007) adaptive capacity may be defined as the ability or potential of a system to respond successfully (i.e. adjust in both behaviour and in resources and technologies) to climate change (including climate variability and extremes), to moderate potential damages, to take advantage of opportunities, or to cope with the consequences of impacts (by recovering or maintaining welfare and/or system function in the face of climatic change) and to profit from new opportunities (assuming climate change affects different actors differentially).

Systems with high adaptive capacity are able to reconfigure themselves more easily after a shock due to an extreme event than systems with a low adaptive capacity. The presence of adaptive capacity has been shown to be a necessary condition for the design and implementation of effective adaptation strategies so as to reduce the likelihood and the magnitude of harmful outcomes resulting from climate change (Brooks and Adger, 2005). Research on vulnerability and adaptive capacity clearly shows that some dimensions of adaptive capacity are generic (with indicators including factors such as education, income and health), while others are specific to particular climate change impacts (such as drought or floods, the adaptation to which may relate to institutions, knowledge and technology; e.g. Yohe and Tol, 2002; Brooks et al., 2005).

Technology can potentially play an important role in adapting to climate change, with engineering solutions representing some of the options that can lead to improved outcomes and increased coping under conditions of climate change.

Adaptive capacity is influenced not only by economic development and technology, but also by social factors such as human capital and governance structures (e.g. Brooks and 
Adger, 2005). As such, adaptive capacity is uneven across societies, and while national-level indicators of vulnerability and adaptive capacity may be used by climate change negotiators, practitioners, and decision-makers in determining policies and allocating priorities for funding and interventions, the usefulness of indicators of generic adaptive capacity and the robustness of the results is not entirely convincing (e.g. Yohe and Tol, 2002; Brooks et al., 2005).

Adaptive capacity is unevenly distributed and highly differentiated within nations due to multiple processes (stresses) of change interacting to influence vulnerability and shape outcomes from climate change (e.g. Ziervogel et al., 2006). Social and economic processes determine the distribution of adaptive capacity, which can be highly heterogeneous within a society or locality, and for individuals and communities it is differentiated by age, class, gender, health and social status. Furthermore, adaptive capacity can change over time, because it may be enhanced or constrained or eroded by factors such as regulations or economic policies determined at the regional or national level that either limit or enhance the freedom of individuals and communities to act, or that make particular potential adaptation strategies either viable or unviable, including violent conflict or the spread of infectious diseases or urbanisation or even trade liberalisation (IPCC, 2007).

\section{A summary of recent findings on projected climate change and hydrological responses over South Africa as a cornerstone to practical adaptive management}

Research recently completed (Schulze, 2011; WRC Project No. K5/1843) was based on an assessment of daily climate outputs from 5 state-of-the-art IPCC (2007) approved atmosphereocean coupled global climate models (GCMs) based on the A2 greenhouse gas emission scenario (Nakićenović et al., 2000). Details of the GCMs are given in Table 1. These multiple GCMs were obtained from, and were statistically downscaled by, the Climate Systems Analysis Group (CSAG) at the University of Cape Town (CSAG, 2008) to over 2600 rainfall stations and over 400 temperature stations with existing longterm daily data over South Africa (Fig. 3). The procedures followed by CSAG were adopted for this and other WRC-funded projects. Daily climate values from the GCMs were derived for three 20-year time slices, viz. the so-called 'present' from 1971 to 1990, a projected 'intermediate future' from 2046 to 2065 and a projected 'more distant future' from 2081 to 2100 , with the daily values adjusted (e.g. by lapse rates; Lumsden et al., 2010) to be representative of the 5838 relatively homogeneous and hydrologically interlinked quinary catchments (Fig. 4; Schulze and Horan, 2010) making up the study region of the RSA, Lesotho and Swaziland. In order to undertake hydrologically related impact studies, the daily climate output from the GCMs (i.e. daily rainfall, maximum and minimum temperatures, from which were also derived daily solar radiation and potential evaporation by the Penman-Monteith technique using approaches refined by Schulze and Chapman (2008) and Schulze et al. (2008)) were used either in direct comparative analyses between projected future and present periods or as input to the daily time-step conceptual-physical ACRU model (Schulze, 1995 and updates) for comparative analyses of hydrological variables.

Results of the climate change impact study (Schulze, 2011) included those of:

- First-order impacts such as projected changes in temperature patterns (magnitude, variability) and in precipitation patterns (magnitude, intra- and inter-annual variability, exceedances of thresholds)

- Second-order impacts such as projected changes in evaporation and in soil-moisture status

- Projected changes in hydrological responses which cover projected changes in streamflow patterns (magnitude, variability, exceedances of thresholds), and changes in flow components, drivers and fluxes (e.g. of stormflows and baseflows)

- Projected changes in droughts in regard to different durations and severities of meteorological as well as hydrological droughts

- Changes in design hydrology with respect to projected changes in magnitudes, frequencies and durations of extreme events (i.e. in short- and long-duration design rainfall, peak discharge and streamflows)

- Practical applications such as projected changes in net irrigation requirements and their environmental consequences and in water available for rainwater harvesting.

\begin{tabular}{|c|c|}
\hline \multicolumn{2}{|c|}{$\begin{array}{l}\text { Table } 1 \\
\text { Information on GCMs, the global climate-change scenarios which were statistically } \\
\text { downscaled by CSAG to climate-station point-scale for application in this research }\end{array}$} \\
\hline Institute & GCM \\
\hline $\begin{array}{l}\text { Canadian Center for Climate Modelling and Analysis } \\
\text { (CCCma), Canada }\end{array}$ & $\begin{array}{l}\text { Name: CGCM3.1(T47) } \\
\text { First published: } 2005 \\
\text { Website: } \underline{\text { http://www.cccma.bc.ec.gc.ca/models/cgcm 3.shtml }}\end{array}$ \\
\hline $\begin{array}{l}\text { Meteo-France / Centre National de Recherches } \\
\text { Meteorologiques } \\
\text { (CNRM), France }\end{array}$ & $\begin{array}{l}\text { Name: CNRM-CM3 } \\
\text { First published: } 2004 \\
\text { Website: } \underline{\text { http://www.cnrm.meteo.fr/scenario2004/indexenglish.html }}\end{array}$ \\
\hline Max Planck Institute for Meteorology (MPI-M), Germany & $\begin{array}{l}\text { Name: ECHAM5/MPI-OM } \\
\text { First published: } 2005 \\
\text { Website: } \text { http://www.mpimet.mpg.de/en/wissenschaft/modelle.html }\end{array}$ \\
\hline NASA / Goddard Institute for Space Studies (GISS), USA & $\begin{array}{l}\text { Name: GISS-ER } \\
\text { First published: } 2004 \\
\text { Website: } \text { http://www.giss.nasa.gov/tools/modelE }\end{array}$ \\
\hline $\begin{array}{l}\text { Institut Pierre Simon Laplace } \\
\text { (IPSL), France }\end{array}$ & $\begin{array}{l}\text { Name: IPSL-CM4 } \\
\text { First published: } 2005 \\
\text { Website: } \underline{\text { http://mc2.ipsl.jussieu.fr/simules.html }}\end{array}$ \\
\hline
\end{tabular}




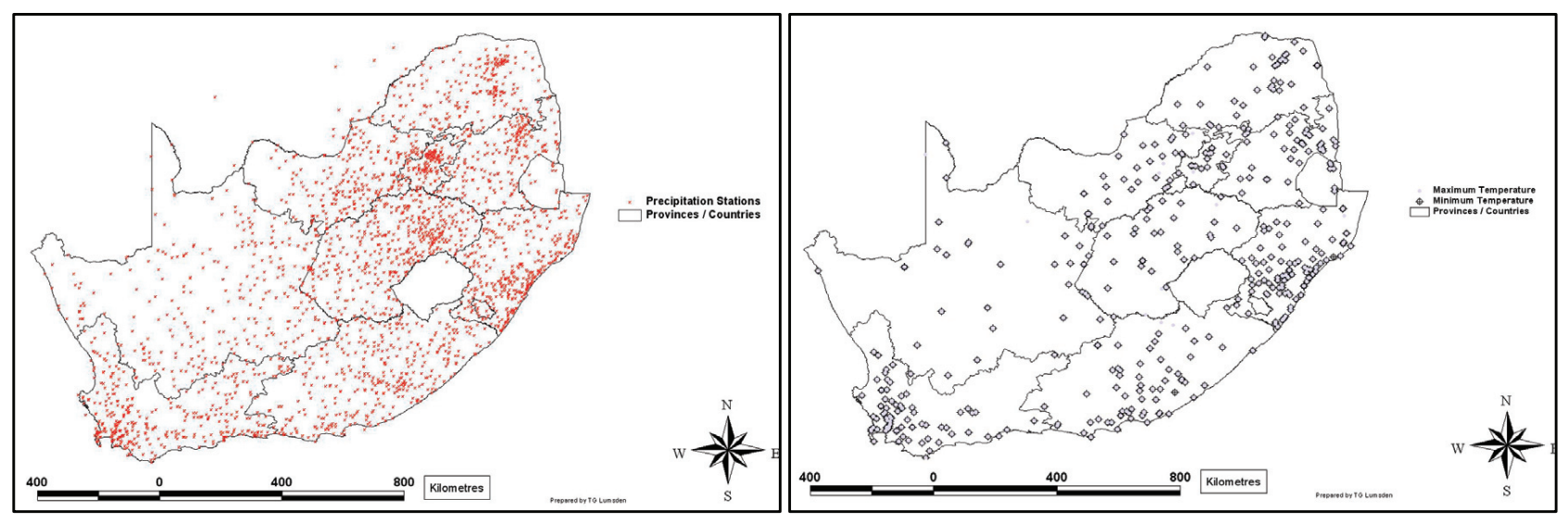

Figure 3

Climate stations for which point scale climate-change scenarios for daily rainfall (left) and daily maximum and minimum temperatures were developed (Lumsden et al., 2010; based on information from CSAG, 2008)

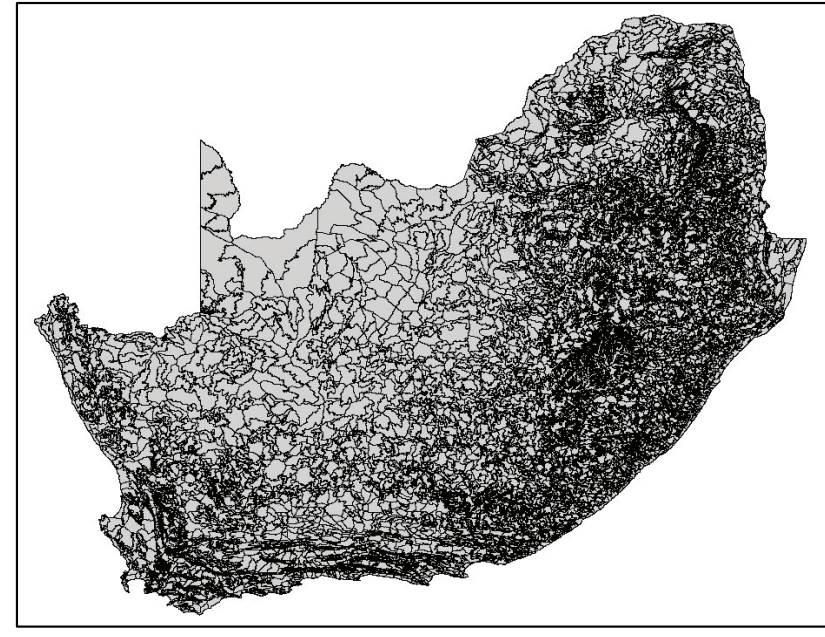

Figure 4

Delineation of the RSA, Lesotho and Swaziland into 5838 quinary catchments (Schulze and Horan, 2010)

During this study a number of key general findings which are considered important to this adaptation paper came to the fore. These are elaborated upon in Schulze (2011), but are summarised below:

- The first is that while there is no doubt that climate change poses new challenges to water resource managers in South Africa, the climatically determined future is certainly not all 'gloom and doom' as some would have it, but neither do the results of this study suggest, as others argue, that 'everything is under control' in the water sector in regard to climate change.

- Some areas within South Africa are likely to become 'winners' for specific projected changes and new waterrelated opportunities will arise, while other areas are likely to become 'losers' in the sense that more waterrelated stresses will be experienced. 'Hotspots' of concern which were identified time and again in the assessments of impacts from the multiple GCMs because of projected reductions in rainfall and associated hydrological repercussions were the southwest of the country, are the west coast and, to a lesser extent, the extreme north of South Africa.

- Results from analyses of ratios of change, based on output from multiple GCMs, show that patterns of hydrological change across South Africa are often projected to differ between future 'average year' conditions vs. future 1-in10 -year wet or 1-in-10-year dry conditions (e.g. in the cases of stormflow, baseflow, sediment yield or net irrigation requirements). Some changes were found to be for the positive, others were found to be potentially more detrimental, and this finding will place an added challenge to adapting to future water management.

- Another finding was that the transitional zone between the winter and summer rainfall area in the western interior of South Africa appears to be an area of high sensitivity and one of inconsistent change, with the highest ratios of change frequently occurring there (e.g. in the case of projected changes to stormflows, peak discharge and design streamflows).

- An intensification (both + and -), and associated expansion in area, was frequently shown for patterns of change in the relatively short period of 35 years from the intermediate future (2046 - 2065) to the more distant future (2081 -2100), illustrating an acceleration and amplification of impacts into the second half of the century when compared with the relatively long 75 -year period between the present $(1971$ - 1990) and the intermediate future. The high sensitivity of this later period was evident in the climate change assessments of, inter alia, accumulated streamflows, thresholds of streamflows exceeded, meteorological droughts, net irrigation requirements and deep percolation losses from irrigated lands.

- In general, the results showed an increase in the year-toyear variability of hydrological responses into the future, and often a quite substantial increase. The increase in variability also tended to be higher into the more distant future than between the intermediate future and present. Examples of increases in inter-annual variability with future projections included those for rainfall, stormflows, accumulated streamflows and sediment yields.

- Patterns of projected change into the future of certain hydrological variables are not always smooth across South Africa. Often strong gradients of change over very short distances were shown from the analyses, sometimes even changing signs from increases to decreases over short distances. Examples of this phenomenon were found in evaluations of changes in baseflows, stormflows and surface runoff losses from irrigated areas. 
- Some components of the hydrological system were found to be more sensitive to climate change than others, sometimes displaying a doubling or more, or a halving or more, of change into the future. Examples of highly sensitive components identified in this study were changes to baseflows, hydrological droughts and surface runoff losses from irrigated lands.

- From an engineering perspective, an important finding was that projected spatial changes to design rainfall and design streamflows vary with return period rather than with critical duration, and this should be factored into future hydraulic designs.

- A strong amplification/intensification was shown when changes in rainfall parameters were compared with equivalent changes in runoff responses, highlighting again the high sensitivity to changes in rainfall in the hydrological cycle. Examples of this amplification include a comparison of hydrological drought (more sensitive) vs. meteorological drought (less sensitive) for the same duration and level of severity, as well as of design streamflows vs. design rainfall for the same duration and return period.

These findings form the scientific basis for practical approaches towards adaptation in South Africa's water-related sector, and these approaches are outlined in the sections which now follow.

\section{Towards a practical approach to adaptation to climate change in the South African water- related sector}

The approach adopted here was first used by the author when he was involved in an international and more generic study which included adaptation options (Appleton et al., 2003), then modified slightly for South Africa (Schulze, 2005a), and now totally overhauled for the local South African situation. As already alluded to, the approach is to identify:

- The major categories in which adaptive capacity can be enhanced

- Important and vulnerable sectors within the broader waterrelated community in South Africa which are likely to be impacted

- The range of foreseen changes the various sectors would have to be coping with, and adapting to, in regard to projected:

- Changes in the drivers of the hydrological system (e.g. in temperature, evaporation and/or rainfall characteristics)

- Changes in the responses of the hydrological system (e.g. in streamflow, or droughts, or irrigation requirements).

\begin{tabular}{|c|c|c|c|}
\hline \multicolumn{4}{|c|}{$\begin{array}{c}\text { Table } 2 \\
\text { Categories and subcategories of adaptation options for water-related sectors in South Africa }\end{array}$} \\
\hline $\begin{array}{l}\text { Cate- } \\
\text { gory }\end{array}$ & $\begin{array}{l}\text { Level } 1 \\
\text { Subcategory }\end{array}$ & $\begin{array}{l}\text { Level } 2 \\
\text { Subcategory }\end{array}$ & $\begin{array}{l}\text { Level } 3 \\
\text { Subcategory }\end{array}$ \\
\hline 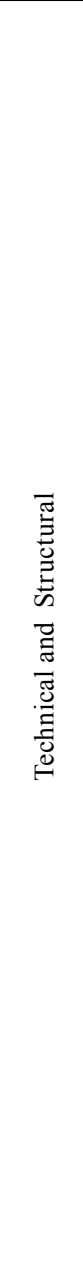 & $\begin{array}{l}\text { Communication of forecasts } \\
\text { to end users } \\
\text { Operations / system } \\
\text { improvements } \\
\text { Water demand management } \\
\text { Indigenous coping strategies } \\
\text { Precipitation enhancement }\end{array}$ & $\begin{array}{l}\text { Structures (i.e. dams, spillways, stormwater systems, levees, sand } \\
\text { bags, wave breaks, vegetative planting) } \\
\text { Near real-time (hours to } 1 \text { day) } \\
\text { Short-term (days to weeks) } \\
\text { Medium-term (years to decades) } \\
\text { Long-term (years to decades) } \\
\text { Awareness creation at higher decision-making level } \\
\text { Awareness creation at operational level (e.g. municipal waste- } \\
\text { water treatment, i.e. WWT) } \\
\text { Training at middle-management level } \\
\text { Training at local level (e.g. municipal WWT operators) } \\
\text { Reservoir operating rules } \\
\text { Retrofitting existing structures } \\
\text { Irrigation scheduling } \\
\text { Wastewater treatment works sanitation }\end{array}$ & $\begin{array}{l}\text { Large reservoirs } \\
\text { Small reservoirs } \\
\text { Artificial recharge } \\
\text { Borehole drilling } \\
\text { Sand dams } \\
\text { Supply leakage control } \\
\text { Irrigation equipment maintenance } \\
\text { Irrigation canal leakage/losses }\end{array}$ \\
\hline
\end{tabular}




\section{Enhancing adaptive capacity}

Building on Appleton et al. (2003) and Schulze (2005a), 5 major categories of enhancing adaptive capacity were identified, viz. those relating to:

- Technological and structural issues

- Knowledge, skills and participation

- Policy instruments

- Risk-sharing and risk-spreading
- Adaptation around changes in uses of land, activities on the land and the location of activities

Each of the 5 major categories was then divided into subcategories which were considered relevant to the South African water-related sector and these were, in turn, further subdivided for consideration in selecting climate change adaptation practices, as shown in Table 2. Note that neither the categories, nor the subcategories, which have been identified, are exhaustive and can be added to.

\begin{tabular}{|c|c|c|c|}
\hline \multicolumn{4}{|c|}{ Table 2 (continued) } \\
\hline $\begin{array}{l}\text { Cate- } \\
\text { gory }\end{array}$ & $\begin{array}{l}\text { Level } 1 \\
\text { Subcategory }\end{array}$ & $\begin{array}{l}\text { Level } 2 \\
\text { Subcategory }\end{array}$ & $\begin{array}{l}\text { Level } 3 \\
\text { Subcategory }\end{array}$ \\
\hline 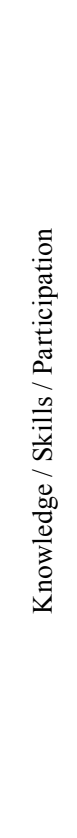 & $\begin{array}{l}\text { Research and development } \\
\text { Development of risk maps/ } \\
\text { flood lines } \\
\text { Communication, training, } \\
\text { dissemination } \\
\text { Participatory approach in } \\
\text { decision-making }\end{array}$ & $\begin{array}{l}\text { Efficient technologies } \\
\text { Upgrading of climate models } \\
\text { Improve forecast skill/dissemination } \\
\text { Development of drought-resistant crops } \\
\\
\text { Awareness creation at higher decision-making level } \\
\text { Awareness creation at operational level (e.g. municipal waste- } \\
\text { water treatment, i.e. WWT) } \\
\text { Training at middle-management level } \\
\text { Training at local level (e.g. municipal WWT operators) } \\
\text { Knowledge management to influence decision making (e.g. } \\
\text { synthesising; re assessing; isolating relevant sectors) } \\
\text { Establishment of inter-departmental learning platforms (e.g. task } \\
\text { teams) } \\
\text { Establishment of an integrated communication system (trends, } \\
\text { priorities, activities, risks) } \\
\text { Creation of ongoing learning and communication platforms } \\
\text { between main water users (e.g. WRC reference group meetings) }\end{array}$ & $\begin{array}{l}\text { Improvements to downscaling/ } \\
\text { RCMs } \\
\text { Fine scale - information provision } \\
\text { relevant to local water managers }\end{array}$ \\
\hline 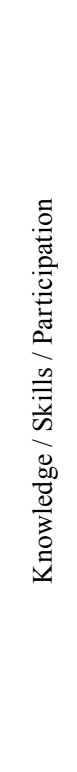 & $\begin{array}{l}\text { Research and development } \\
\text { Development of risk maps/ } \\
\text { flood lines } \\
\text { Communication, training, } \\
\text { dissemination } \\
\text { Participatory approach in } \\
\text { decision-making }\end{array}$ & $\begin{array}{l}\text { Efficient technologies } \\
\text { Upgrading of climate models } \\
\text { Improve forecast skill/dissemination } \\
\text { Development of drought-resistant crops } \\
\\
\text { Awareness creation at higher decision-making level } \\
\text { Awareness creation at operational level (e.g. municipal waste- } \\
\text { water treatment, i.e. WWT) } \\
\text { Training at middle-management level } \\
\text { Training at local level (e.g. municipal WWT operators) } \\
\text { Knowledge management to influence decision making (e.g. } \\
\text { synthesising; re assessing; isolating relevant sectors) } \\
\text { Establishment of inter-departmental learning platforms (e.g. task } \\
\text { teams) } \\
\text { Establishment of an integrated communication system (trends, } \\
\text { priorities, activities, risks) } \\
\text { Creation of ongoing learning and communication platforms } \\
\text { between main water users (e.g. WRC reference group meetings) }\end{array}$ & $\begin{array}{l}\text { Improvements to downscaling/RCMs } \\
\text { Fine scale - information provision } \\
\text { relevant to local water managers }\end{array}$ \\
\hline 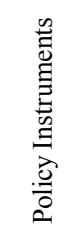 & $\begin{array}{l}\text { International conventions } \\
\text { (e.g. UNFCCC) } \\
\text { International water } \\
\text { agreements } \\
\text { International trade }\end{array}$ & & \\
\hline
\end{tabular}




\begin{tabular}{|c|c|c|c|}
\hline \multicolumn{4}{|c|}{ Table 2 (continued) } \\
\hline $\begin{array}{l}\text { Cate- } \\
\text { gory }\end{array}$ & $\begin{array}{l}\text { Level } 1 \\
\text { Subcategory }\end{array}$ & $\begin{array}{l}\text { Level } 2 \\
\text { Subcategory }\end{array}$ & $\begin{array}{l}\text { Level } 3 \\
\text { Subcategory }\end{array}$ \\
\hline 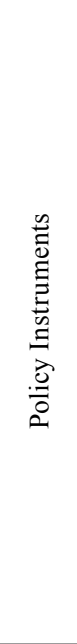 & $\begin{array}{l}\text { National water master plans } \\
\text { Other national master plans } \\
\text { Provincial strategies } \\
\text { Local strategies } \\
\begin{array}{l}\text { Disaster management } \\
\text { policies/action plans }\end{array}\end{array}$ & $\begin{array}{l}\text { National Water Act of } 1998 \\
\text { Water Services Act of } 1997 \\
\text { National Water Resource Strategy of } 2004 \text { and of } 2011 \text { (unpub- } \\
\text { lished at the time of printing) } \\
\text { Water for Growth and Development Framework of } 2009 \\
\text { Catchment management strategies (CMSs) } \\
\text { Estuary management plans } \\
\text { National Environmental Management Act (NEMA) } \\
\text { Conservation of Agricultural Resources Act (CARA) } \\
\text { Integrated Development Plans (IDPs) } \\
\text { Provincial Growth \& Development Strategies (PGDS) } \\
\text { Provincial water reconciliation Strategies } \\
\text { Municipal by-laws }\end{array}$ & \\
\hline 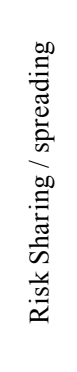 & \begin{tabular}{|l} 
Private sector strategies \\
Public sector strategies
\end{tabular} & $\begin{array}{l}\text { Insurance } \\
\text { Banks } \\
\text { Stock exchange } \\
\text { Drought relief by government } \\
\text { Flood relief by government }\end{array}$ & $\begin{array}{l}\text { Primary insurers } \\
\text { Re-insurance } \\
\text { Micro-insurance } \\
\text { Development } \\
\text { Private } \\
\text { Micro-lenders }\end{array}$ \\
\hline 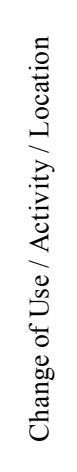 & $\begin{array}{l}\text { Land-use measures } \\
\text { Crop changes } \\
\text { Resettlement } \\
\begin{array}{l}\text { Maintenance or re-establish- } \\
\text { ment of natural capital (e.g. } \\
\text { wetlands, estuaries, buffers, } \\
\text { etc.) }\end{array}\end{array}$ & $\begin{array}{l}\text { Conservation structures } \\
\text { Adaptive spatial planning } \\
\text { Tillage practices } \\
\text { Use of organic (instead of chemical) fertilisers } \\
\text { Alien invasive clearing activities }\end{array}$ & \\
\hline
\end{tabular}

\section{Impacted sectors}

Many water-related sectors and institutions in South Africa are likely to be impacted upon, or are vulnerable to climate change, and in this initial investigation the following 17 were identified, in each case as they relate to water:

- National water planning departments (e.g. Department of Water Affairs (DWA))

- Regional water planners (e.g. catchment management agencies (CMAs))

- Bulk water suppliers (e.g. Umgeni Water)

- Water user associations/irrigation boards (e.g. Pongola Irrigation Board)

- Municipalities

- Disaster risk management (national, provincial, local)

- Rain-fed (dryland) agriculture, including livestock activities

- Irrigated agriculture

- Insurance industry
- Road transport sector (e.g. SANRAL, provincial roads departments, local government)

- Thermal electric power industry (e.g. Eskom)

- Hydroelectric power

- Poor rural communities

- Informal urban communities

- Individual households

- Aquatic ecosystems (e.g. estuaries, wetlands, buffers, environmental flows)

- Terrestrial ecosystems (e.g. biodiversity, land degradation, fire, alien invasive plants)

\section{Coping with/adapting to projected changes in drivers and responses}

The above sectors, which make up the wider water community in South Africa and include those who manage water, will need to cope with, and adapt to, a range of foreseen changes to climate drivers and the hydrological responses to the changes of 
those drivers. Anticipated changes to the following are considered in this study, noting that this list is not exhaustive and that the distinction between what are considered drivers and what are seen as responses is not always clear-cut. References to chapters in Schulze (2011) and to other sources of information on projected impacts in South Africa are also provided.

\section{Drivers: Changes in...}

- $\quad$ Enhanced evaporation (Schulze, 2011: Ch. 4.1, 4.2, 8.1): This is the additional evaporation, over and above that under present climatic conditions, from open water bodies such as dams and wetlands as well as that from the plantsoil system. Chapters referred to under enhanced evaporation cover projected changes to reference potential evaporation, to soil-water content and to additional evaporation from open water bodies.

- Heat waves (Schulze and Kunz, 2010: Ch. 3.4): Heat waves are defined as 3 consecutive days with maximum temperatures exceeding $30^{\circ} \mathrm{C}$ on each day, while extreme heat waves have 3 consecutive days each exceeding $35^{\circ} \mathrm{C}$.

- Water temperature (Barichievy et al., 2010a: Ch. 13, 14): Water temperature is computed for each day and for each quinary catchment from a maximum air temperaturerelated empirical equation developed in South Africa, and then combined with the computed water temperature from any upstream catchment, assuming perfect mixing of the waters. Increased water temperatures could affect, inter alia, cooling for power stations, the quality of water for irrigation, dissolved oxygen content of water, the rates of chemical reactions in water as well as have wide-ranging repercussions in the health sector through water-borne diseases.

- Thresholds of rainfall exceeded (Schulze, 2011: Ch. 3.6): These are the changes in the number of days per year on which daily rainfall exceeds hydrologically critical amounts, e.g. $2 \mathrm{~mm} / \mathrm{d}$ which implies runoff from impervious urban areas and also exceeds the plant interception threshold, or $10 \mathrm{~mm} / \mathrm{d}$ which implies that stormflow and sediment yield might be generated, or $25 \mathrm{~mm} / \mathrm{d}$ which might imply a more significant hydrograph.

- Design precipitation of short duration (5 min - 24 h) (Schulze, 2011: Ch. 7.1): This is the change in rainfall expected statistically only once in 2 or 5 or 10 or 20 years for a period of time ranging from anything between 5 min and $24 \mathrm{~h}$, with values used in the sizing and design of hydraulic structures, for example, of stormwater drainage systems.

- Design precipitation of long duration $(1 d-7 d)$ (Schulze, 2011: Ch. 7.2): Implied here are changes to the rainfall expected statistically only once in 2 or 5 years or 10 or 20 years falling over a period of time ranging from $1 \mathrm{~d}$ to $7 \mathrm{~d}$ (consecutive days) and used, for example, as input in regional flood analyses or in the spillway design of dams on large catchments.

\section{Responses: Changes in...}

- Soil moisture (Schulze, 2011: Ch. 4.2): These are changes in the water content within the soil profile, which determines whether a plant experiences either no water stress, or mild or severe stress because of a lack of soil water or water-logging of the soil. Changes in soil water content on a given day determine, inter alia, changes to the potential for either more or less stormflow to be generated from a given amount of rainfall as well as changes in the number of irrigation applications.

- Groundwater recharge (Schulze, 2011: Ch. 5.3): Recharge in this instance emanates from soil water percolating through the soil profile of a landscape under wet conditions to beyond the root zone of plants into the groundwater zone, to recharge the groundwater store and then become available for slow release into the stream as baseflow.

- Thresholds of streamflows exceeded (Schulze, 2011: Ch. 5.5): These are projected changes in the number of days per year with daily streamflows, accumulated at a point of interest from all upstream catchments, exceeding hydrologically critical amounts. Critical thresholds include changes in days with no flow or days with significant amounts of high flows which might result in filling dams with water or may be indicators of flooding.

- Flash floods (Schulze, 2011: Ch. 5.6, 7.1): These are changes to severe floods occurring over a short period of time and usually over a small catchment area only, frequently the result of severe convective activity from thunderstorms with high intensity rainfall. Chapters referred to under flash floods cover projected changes in peak discharge per quinary catchment and over short duration (5 min and up to $24 \mathrm{~h}$ ) design rainfall.

- Regional floods (Schulze, 2011: Ch. 5.2, 5.4, 7.3): Considered here are changes in floods with high waters occurring over several days and covering substantial areas, usually in the $1000 \mathrm{~s}$ of $\mathrm{km}^{2}$, inundating areas around the channel system, and resulting from widespread rains over a period of several consecutive days, with considerable amounts of rain often falling on already wet catchments. Chapters referred to under changes in regional floods cover projected changes to 1:10 year stormflows from individual quinaries, 1:10 year accumulated streamflows from all upstream catchments and design streamflows for a range of durations from $1 \mathrm{~d}$ to $7 \mathrm{~d}$ and for a range of return periods from 2 to 20 years.

- Design streamflow magnitudes (Schulze, 2011: Ch. 7.3): These are projected changes to streamflows at a location with flood waters accumulated from all upstream catchments, and where the magnitude of such streamflows are expected statistically only once in 2 or 5 or 10 or 20 years and experienced over a period of time ranging from $1 \mathrm{~d}$ to 7 $\mathrm{d}$ (consecutive days). This information is used, for example, in flood warnings and in the spillway design of dams on large catchments.

- Design peak discharge (Schulze, 2011: Ch. 5.6):

Considered here are changes, at the exit of a quinary catchment, in the peak discharge (in $\mathrm{m}^{3} / \mathrm{s}$ ) on a given day, where such a peak discharge is expected statistically only once in 2 or 5 or 10 or 20 years and with the information used, for example, in flood warnings and in the spillway design of dams.

- Agricultural droughts (Schulze, 2011: Ch. 4.2, 6.1, 6.2, 8.2): These are changes in the frequencies of occurrence of droughts of different severities such as mild droughts (i.e. the worst in 3 years or less frequently), moderate (worst in 5 years or less frequently) or severe droughts (worst in 10 years or less frequently), which are experienced over a period of either months or years, in which soil-moisture deficits result in crop-yield losses of different severities. While changes in agricultural droughts per se were not assessed explicitly in Schulze (2011), the chapters referred 
to above cover agricultural droughts implicitly through projected changes to soil-water content, changes to frequencies of meteorological and hydrological droughts for a range of durations and severities, as well as changes to net irrigation requirements.

- Hydrological droughts (Schulze, 2011: Ch. 5.5, 6.1, 6.2, 8.1, 8.2): Implied here are changes in droughts of different severities such as mild hydrological droughts (i.e. the worst in 3 years or less frequently), moderate (worst in 5 years or less frequently) or severe hydrological droughts (worst in 10 years or less frequently), which are experienced over a period of either months or years, and in which accumulated streamflows at a location within a catchment are below the expected. Hydrological droughts may result in water shortages or curtailments/rationing being applied. Chapters referred to under hydrological droughts cover changes to hydrological droughts per se as well as projected changes to the number of times per year that thresholds of specified streamflows are exceeded, and also changes to frequencies of meteorological droughts of different durations/severities and changes to net irrigation requirements.

- Surface water supply (Schulze, 2011: Ch. 5.2, 5.4, 6.1, 6.2, 8.1, 8.4): Changes in water supply derive from streamflows in a catchment and are made up of accumulated stormflows and baseflows from all areas upstream of the point of interest. Where reference is made to changes in water supply, the chapters referred to cover a range of related aspects including projected changes to stormflows from individual quinaries, accumulated streamflows from all upstream catchments, changes to meteorological and hydrological droughts of a range of durations and severities as well as the additional water evaporated from open water bodies in South Africa.

- Transboundary flows (quantity and quality) (Schulze, 2011: Ch. 5.4, 5.5, 5.7, 6.2, 7.2, 7.3, 8.1, 8.3): International transboundary flows in the South African context imply flows emanating either from another country and entering South Africa, e.g. the Orange-Senqu from Lesotho, or flows from South Africa exiting into another country, e.g. the Sabie or Olifants flowing into Mozambique, or rivers shared between South Africa and another country through a common border, e.g. the Limpopo with Zimbabwe or the Orange with Namibia. Chapters referred to under changes to transboundary flows cover a range of issues of concern with international rivers, including projected changes to accumulated streamflows, to the number of times per year that thresholds of specified streamflows are exceeded, to sediment yield, hydrological droughts, changes to longduration design rainfalls and streamflows, as well as to projected changes in net irrigation demand and in percolation and runoff losses from irrigated areas.

- Groundwater supply: These are changes in water supplied by abstractions from a subterranean source, e.g. a deep aquifer, which is not connected to a stream.

- Water quality - sediments (Schulze, 2011: Ch. 5.7): Changes in the deterioration of water quality as a result of turbid waters and high silt content resulting from a sediment load emanating from the landscape component of a catchment are implied here. The main causes of change into the future in the context of this research would be related to changes in flow volumes and peak discharges from a catchment, while from a more integrated perspective, simultaneous changes to vegetative cover above as well as on the ground, and land management practices, could play a vital role in changes in sediment yields. Changes in sediment yields have implications, inter alia, for the design life of dams, costs of water treatment and suitability of the water for irrigation.

- Water quality - chemical (Schulze, 2011: Ch. 8.3): Implied here is further deterioration of water quality under climate change as a result of, inter alia, changes in point-source pollutants or non-point source pollutants from agricultural chemicals, metals from mining or atmospheric deposits, bearing in mind that the rate of many chemical reactions speeds up with increased temperature. Any negative changes in water quality are detrimental to the aquatic habitat and to downstream water users, and introduce higher water purification costs.

- Water quality - biological: Deterioration of water quality as a result, inter alia, of pathogens and organics from urban and rural areas, which often derive from sewage effluent discharges into non-existent or dysfunctional wastewater treatment plants in many of the formal and informal urban areas, frequently manifests itself through excessively high $E$. coli concentrations in rivers and stored water, and with often severe health consequences.

- Environmental flows (Barichievy et al., 2010b: Ch. 12): Environmental flows are flow requirements in river reaches needed to sustain aquatic habitats. Changes in magnitudes, frequencies, durations, timing and rates of flows in a river reach, all of which are vital components of environmental flows, are projected under future climatic conditions.

- Storm surges: Storm surges are a coastal/near coastal phenomenon in which water surges upstream into estuaries and river channels, resulting in the overtopping of river banks or allowing rivers to expand sideways, with implications on river bank infrastructure. In association with projected sea-level rise, storm surges are projected to increase in frequency and magnitude into the future (IPCC, 2007).

- Sea-level rise: Sea-level rises of between $1.5 \mathrm{~mm} / \mathrm{a}$ and $7.0 \mathrm{~mm} / \mathrm{a}$ as a result of expansion of oceanic waters due to higher temperatures and melting ice masses (IPCC, 2007) can have hydrological consequences, inter alia through sea-water intrusion into coastal freshwater lenses and soil salinisation.

\section{Modus operandi on identifying the range of foreseen changes that various sectors would have to cope with and adapt to}

Of the 17 water-related sectors previously identified in this study as being vulnerable to, and likely to be impacted by, climate change, viz. those ranging from national water planning departments through the regional water management agencies, municipalities, disaster risk management, agriculture sectors, the insurance/transport/power industries, individuals and communities as well as ecosystems, 5 divergent sectors are selected in this paper as case studies to illustrate the approach adopted to identifying practical adaptation options. These 5 sectors are national water planning departments, municipalities, rain-fed agriculture, the insurance industry and aquatic ecosystems. For each of these 5 selected sectors a self-standing (i.e. independent) table was generated with:

- The major categories and the subcategories in which adaptive capacity can be enhanced in that specific sector being listed in the first column (with the respective tables being of different lengths, depending on the anticipated climate change ramifications for that sector) 
- The drivers of the hydrological system as well as responses of the hydrological system which are anticipated to change, then being listed against each category/subcategory in the second column

- A cross-reference then being made in the third column to chapters from Schulze (2011) as well as to some other sources of information from which more detail can be gleaned and maps of projected impacts obtained. These cross-references are not exhaustive and would be added to in future.

\section{Water-related sector adaptation}

Five sectors were selected for detailed case studies on adaptive management options, viz. national water planners, municipalities, rain-fed (dryland) agriculture, the insurance industry and aquatic ecosystems, and the 5 case studies are presented below.

\section{Case Study 1: The national water planning department (e.g. Department of Water Affairs)}

The national water planning department would fall under the 'higher level' adaptation category of Theesfeld et al. (2011) in having the responsibility for intentional, anticipatory, proactive, long term and strategic adaptation in the country's overall water sector, ideally with high adaptive capacity in its midst, both in regard to human/conceptual capacity and governance structures. Table 3 identifies that within its responsibilities in leading the nation's water sector into an uncertain climate (and other) future would be planning/management of large dams, ensuring that early warning systems are functioning effectively, revisiting dam operating rules, promoting water demand management and updating flood lines. A particular emphasis would have to be revisiting international agreements

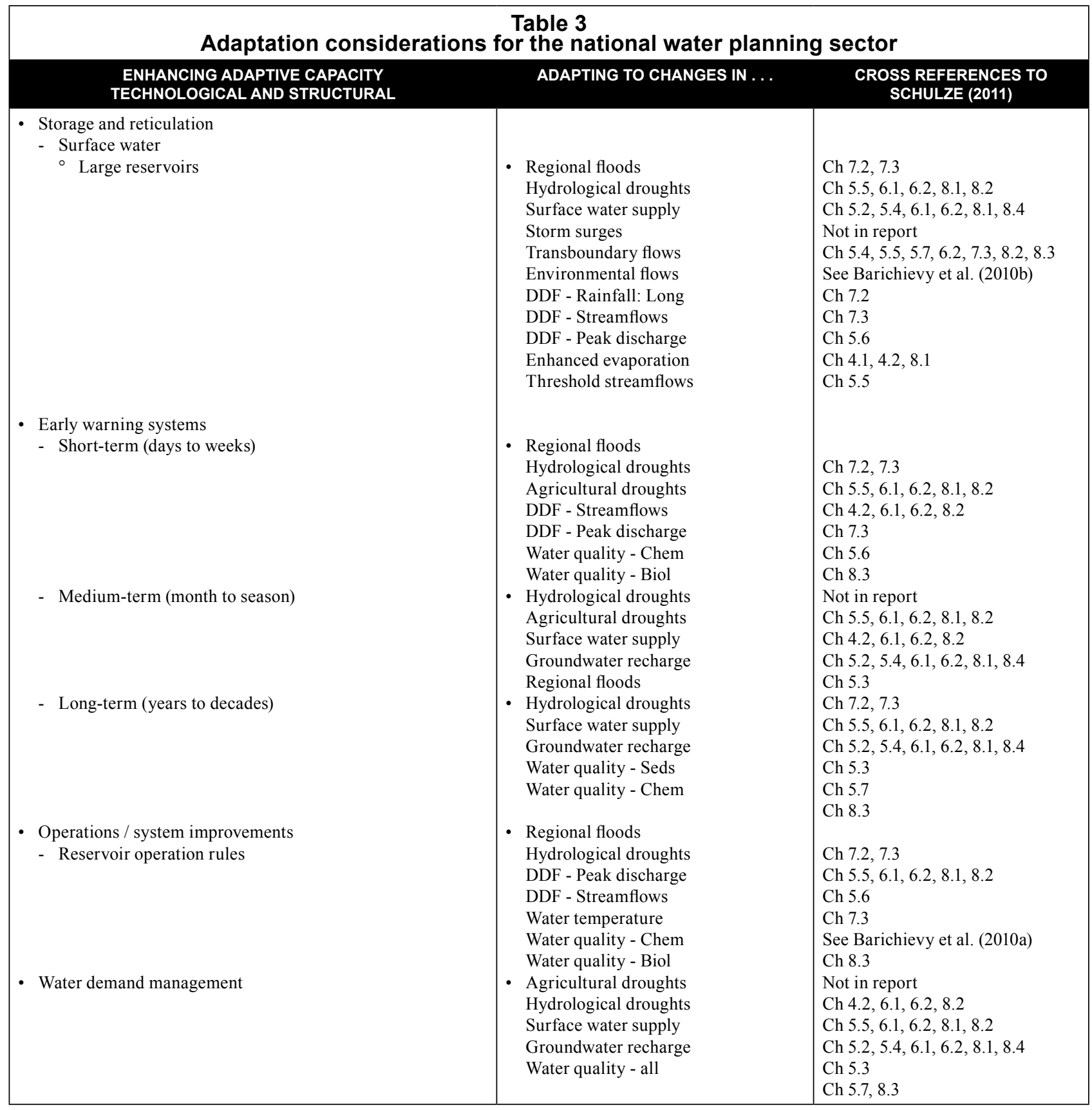

(Table to be continued on next page) 


\begin{tabular}{|c|c|c|}
\hline \multicolumn{3}{|c|}{ Table 3 (continued) } \\
\hline KNOWLEDGE / SKILLS / PARTICIPATION & ADAPTING TO CHANGES IN . . . & CROSS REFERENCES \\
\hline $\begin{array}{l}\text { - Research and development } \\
\text { - Efficient technologies } \\
\text { - Upgrading of climate models } \\
\text { o Improvements to downscaling / RCMs } \\
\text { - Improvement of forecast skill / dissemination } \\
\text { - Development of risk maps / flood lines } \\
\text { - Communication / training / dissemination } \\
\text { - Awareness creation at higher-decision making level } \\
\text { - Participatory approach in decision-making } \\
\text { - Establishment of inter-departmental learning platforms } \\
\text { - Establishment of integrated communication systems }\end{array}$ & $\begin{array}{l}\text { - All } \\
\text { - All } \\
\text { - All } \\
\text { - All } \\
\text { - Regional floods } \\
\text { Flash floods } \\
\text { Hydrological droughts } \\
\text { DDF - Rainfall: Short } \\
\text { DDF - Rainfall: Long } \\
\text { DDF - Discharge } \\
\text { Sea-level rise } \\
\text { Storm surges } \\
\text { - All } \\
\text { - All } \\
\text { - All }\end{array}$ & $\begin{array}{l}\text { Ch } 7.2,7.3 \\
\text { Ch } 5.6,7.1 \\
\text { Ch } 5.5,6.1,6.2,8.1,8.2 \\
\text { Ch } 7.1 \\
7.2 \\
5.6 \\
\text { Not in report } \\
\text { Not in report }\end{array}$ \\
\hline POLICY INSTRUMENTS & ADAPTING TO CHANGES IN . & CROSS REFERENCES \\
\hline $\begin{array}{l}\text { - International conventions (e.g. UNFCCC) } \\
\text { - International water agreements } \\
\text { - National water master plans } \\
\text { - National Water Act of } 1998 \\
\text { - Other national Water Resource Strategy } \\
\text { - National Environmentans } \\
\text { - Conservation of Agricultural Resources Act } \\
\text { - Disaster management policies/plans }\end{array}$ & $\begin{array}{l}\text { - All } \\
\text { - All } \\
\text { - All } \\
\text { - Environmental flows } \\
\text { - Water quality - Seds } \\
\text { Water quality - Chem } \\
\text { - Flash floods } \\
\text { Regional floods } \\
\text { Agricultural droughts } \\
\text { Hydrological droughts }\end{array}$ & $\begin{array}{l}\text { See Barichievy et al. (2010b) } \\
\text { Ch } 5.7 \\
\text { Ch } 8.3 \\
\text { Ch } 5.6,7.1 \\
\text { Ch } 5.2,5.4,7.3 \\
\text { Ch } 4.2,6.1,6.2,8.2 \\
\text { Ch } 5.5,6.1,6.2,8.1,8.2\end{array}$ \\
\hline RISK SHARING / SPREADING & ADAPTING TO CHANGES IN . . & CROSS REFERENCES \\
\hline $\begin{array}{l}\text { - Private sector strategies } \\
\text { - Banks } \\
\circ \quad \text { Development }\end{array}$ & - All & \\
\hline CHANGE OF USE / ACTIVITY I LOCATION & ADAPTING TO CHANGES IN ... & CROSS REFERENCES \\
\hline $\begin{array}{l}\text { - Land-use measures } \\
\text { - Adaptive spatial planning }\end{array}$ & $\begin{array}{l}\text { - Flash floods } \\
\text { Regional floods } \\
\text { DDF - Streamflows } \\
\text { Surface water supply } \\
\text { Water quality - Seds } \\
\text { Water quality - Chem } \\
\text { Water quality - Biol } \\
\text { Sea-level rise } \\
\text { Storm surges }\end{array}$ & $\begin{array}{l}\text { Ch } 5.6,7.1 \\
\text { Ch } 7.2,7.3 \\
\text { Ch } 7.3 \\
\text { Ch } 5.2,5.4,6.1,6.2,8.1,8.4 \\
\text { Ch } 5.7 \\
\text { Ch } 8.3 \\
\text { Not in report } \\
\text { Not in report } \\
\text { Not in report }\end{array}$ \\
\hline
\end{tabular}

with neighbouring countries in light of the latest findings on projected climate change impacts, updating national water and related master plans as well as contributing to disaster management policies/plans from a water perspective. Under the 'change of use' category of enhancing adaptive capacity would have to be an emphasis on water-related issues in adaptive spatial planning.

\section{Case Study 2: Municipalities}

Considerations in regard to water-related adaptation to climate change by municipalities in South Africa cover a very wide range of options. The reason for this is that municipalities vary from sophisticated metropolitan conurbations serving many millions of people with water to the small village in remote areas, from municipalities with highly functional water supply and wastewater treatment works with high scores in their 'Blue Drop' and 'Green Drop' certification (DWA, 2011) to those with dysfunctional infrastructure, from coastal municipalities where desalination plants may be an option to those far from surface water resources and dependent on (possibly dwindling) groundwater supplies, and from those municipalities with a high level of human capacity to those lacking in technical skills.

Consequently, Table 4 covers virtually the entire range of proposed enhancements to adaptation to climate change, depending on the situations outlined above, and ranging from a re-look at the sizing and functioning of large and small reservoirs to considering artificial recharge, borehole drilling, the construction of sand dams or utilising rainwater harvesting techniques, with an emphasis also on supply leakage control, 


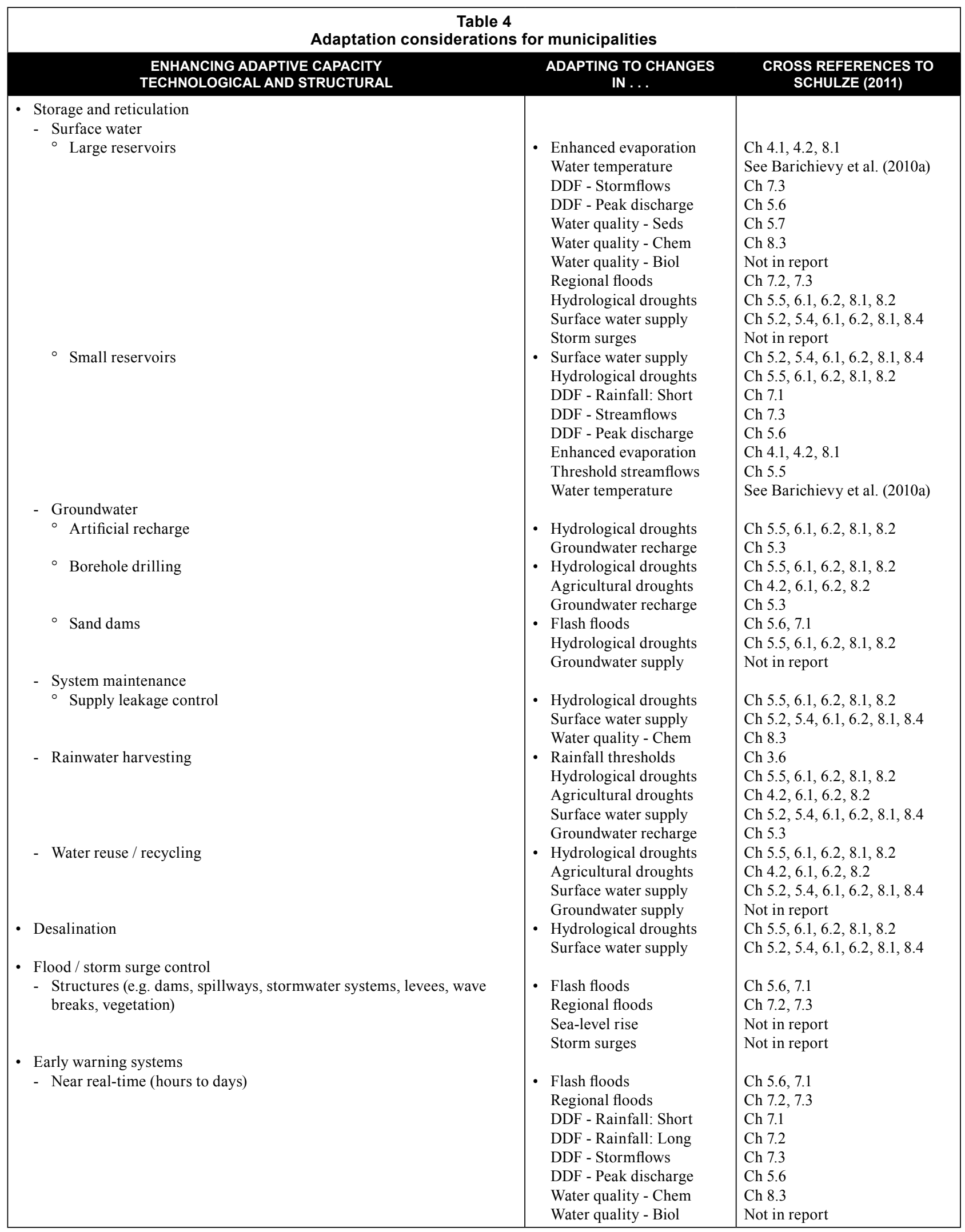

(Table to be continued on next page)

retrofitting of existing infrastructure and recycling/reuse of water. Coastal municipalities may need to look into flood-surge control and municipalities should be linked to early warning systems spanning near-real time to long-term forecasts. A strong emphasis for municipalities has to be on communicating and training in climate change issues at appropriate levels as well as on a participatory approach to decision-making with respect to climate change. Municipalities will also need to take cognizance not only of national level water (and other) master plans, but also those at provincial and local levels, while under 
- Short-term (days to weeks)

- Medium-term (month to season)

- Long-term (years to decades)

- Communication of forecasts to end users

- Awareness creation at operational level

- Training at local level

- Water quality and quantity monitoring systems

- Operations / system improvements

- Reservoir operation rules

- Retrofitting existing structures
- Regional floods

Hydrological droughts Agricultural droughts DDF - Rainfall: Long DDF - Streamflows DDF - Peak discharge Streamflow thresholds Water Quality - Chem Water Quality - Biol

- Hydrological droughts Agricultural droughts Surface water supply Groundwater recharge

- Hydrological droughts Surface water supply Groundwater supply

- Flash flood Regional floods Hydrological droughts Agricultural droughts

Sea-level rise

Storm surges

- Flash floods Regional floods Storm surges

- All

- Flash floods Regional floods Hydrological droughts Environmental flows

- Flash floods Regional floods DDF - Rainfall: Short DDF - Streamflows DDF - Peak discharge

Sea-level rise

Storm surges

Surface water supply Groundwater recharge

- Water demand management
- Agricultural droughts Hydrological droughts Surface water supply Groundwater recharge Water quality - Chem Water quality - Biol
Ch 7.2, 7.3

Ch $5.5,6.1,6.2,8.1,8.2$

Ch $4.2,6.1,6.2,8.2$

Ch 7.2

Ch 7.3

Ch 5.6

Ch 5.5

Ch 8.3

Not in report

Ch 5.5, 6.1, 6.2, 8.1, 8.2

Ch $4.2,6.1,6.2,8.2$

Ch 5.2, 5.4, 6.1, 6.2, 8.1, 8.4

Ch 5.3

Ch 5.5, 6.1, 6.2, 8.1, 8.2

Ch 5.2, 5.4, 6.1, 6.2, 8.1, 8.4

Not in report

Ch 5.6, 7.1

Ch $7.2,7.3$

Ch 5.5, 6.1, 6.2, 8.1, 8.2

Ch $4.2,6.1,6.2,8.2$

Not in report

Not in report

Ch 5.6, 7.1

Ch 5.2, 5.4, 7.3

Not in report

Ch 5.6, 7.1

Ch $7.2,7.3$

Ch 5.5, 6.1, 6.2, 8.1, 8.2

See Barichievy et al. (2010b)

Ch 5.6, 7.1

Ch $7.2,7.3$

Ch 7.1

Ch 7.3

Ch 5.6

Not in report

Not in report

Ch $5.2,5.4,6.1,6.2,8.1,8.4$

Ch 5.3

Ch $4.2,6.1,6.2,8.2$

Ch $5.5,6.1,6.2,8.1,8.2$

Ch $5.2,5.4,6.1,6.2,8.1,8.4$

Ch 5.3

Ch 8.3

Not in report

- Research and development

- Efficient technologies

- Upgrading of climate models

- Fine-scale information provision relevant to local water managers

- Improvement of forecast skill / dissemination

- Communication / training / dissemination

- Awareness creation at operations level (e.g. senior municipal officials re. budget allocation and future special planning)

- Training at middle-management level

- Training at local level (e.g. municipal WWT operators)

- Participatory approach in decision-making

- Establishment of inter-departmental learning platforms

- Establishment of integrated communications systems

- Creation of ongoing learning and communication platforms between main water users 


\begin{tabular}{|c|c|c|}
\hline \multicolumn{3}{|c|}{ Table 4 (continued) } \\
\hline POLICY INSTRUMENTS & $\begin{array}{c}\text { ADAPTING TO CHANGES } \\
\text { IN . . }\end{array}$ & CROSS REFERENCES \\
\hline $\begin{array}{l}\text { - National water master plans } \\
\text { - National Water Act of } 1998 \\
\text { - National Water Resource Strategy } \\
\text { - Water Services Act of } 1997 \\
\text { - Catchment management strategies } \\
\text { - River management plans } \\
\text { - Other national strategies } \\
\text { - Integrated development plans } \\
\text { - Provincial strategies } \\
\text { - Provincial growth and development strategies } \\
\text { - Local strategies } \\
\text { - Municipal by-laws } \\
\text { - Disaster management policies / plans }\end{array}$ & $\begin{array}{l}\text { - All } \\
\text { - All } \\
\text { - All } \\
\text { - All } \\
\text { - All } \\
\text { - All } \\
\text { - All } \\
\text { - All } \\
\text { - All }\end{array}$ & \\
\hline RISK SHARING / SPREADING & $\begin{array}{c}\text { ADAPTING TO CHANGES } \\
\text { IN . . }\end{array}$ & CROSS REFERENCES \\
\hline $\begin{array}{l}\text { - Private sector strategies } \\
\text { - Insurance } \\
\circ \text { Re-insurance }\end{array}$ & $\begin{array}{l}\text { - Regional floods } \\
\text { Flash floods }\end{array}$ & $\begin{array}{l}\text { Ch } 7.2,7.3 \\
\text { Ch } 5.6,7.1\end{array}$ \\
\hline CHANGE OF USE / ACTIVITY / LOCATION & $\begin{array}{c}\text { ADAPTING TO CHANGES } \\
\text { IN . . }\end{array}$ & CROSS REFERENCES \\
\hline $\begin{array}{l}\text { - Land-use measures } \\
\text { - Conservation structures } \\
\text { - Adaptive spatial planning } \\
\text { - Alien invasive clearing activities } \\
\text { Resettlement } \\
\text { - Maintaining or re-establishment of natural capital (e.g. wetlands, buffers, etc.) }\end{array}$ & $\begin{array}{l}\text { - Flash floods } \\
\text { Regional floods } \\
\text { DDF - Rainfall: Short } \\
\text { DDF - Streamflows } \\
\text { DDF - Peak discharge } \\
\text { Sea-level rise } \\
\text { Storm surges } \\
\text { Agricultural droughts } \\
\text { - Flash floods } \\
\text { Regional floods } \\
\text { DDF - Rainfall: Short } \\
\text { DDF - Rainfall: Long } \\
\text { DDF - Streamflow } \\
\text { DDF - Peak discharge } \\
\text { Sea-level rise } \\
\text { Storm surges } \\
\text { - Surface water supply } \\
\text { - Flash floods } \\
\text { Regional floods } \\
\text { Rainfall thresholds } \\
\text { DDF - Rainfall: Short } \\
\text { DDF - Rainfall: Long } \\
\text { DDF - Streamflows } \\
\text { DDF - Peak discharge } \\
\text { Flash floods } \\
\text { Regional floods } \\
\text { Water quality - Seds } \\
\text { Water quality - Chem } \\
\text { Water quality - Biol }\end{array}$ & $\begin{array}{l}\text { Ch } 5.6,7.1 \\
\text { Ch } 7.2,7.3 \\
\text { Ch } 7.1 \\
\text { Ch } 7 / 3 \\
\text { Ch } 5.6 \\
\text { Not in report } \\
\text { Not in report } \\
\text { Ch } 4.2,6.1,6.2,8.2 \\
\text { Ch } 5.6,7.1 \\
\text { Ch } 7.2,7.3 \\
\text { Ch } 7.1 \\
\text { Ch } 7.2 \\
\text { Ch } 7.3 \\
\text { Ch } 5.6 \\
\text { Not in report } \\
\text { Not in report } \\
\text { Ch } 5.2,5.4,6.1,6.2,8.1,8.4 \\
\text { Ch } 5.6,7.1 \\
\text { Ch } 5.2,5.4,7.3 \\
\text { Ch } 3.6 \\
\text { Ch } 7.1 \\
\text { Ch } 7.2 \\
\text { Ch } 7.3 \\
\text { Ch } 5.6 \\
\text { Ch } 5.6,7.1 \\
\text { Ch } 5.2,5.4,7.3 \\
\text { Ch } 5.7 \\
\text { Ch } 8.3 \\
\text { Not in report }\end{array}$ \\
\hline
\end{tabular}

changes to land uses and activities a wide range of options also needs to be taken account of, from conservation structures to adaptive spatial plans in light of climate change impacts, resettlement and maintenance of natural capital. While commonalities exist in adapting to climate change, it needs to be emphasised that in some respects each municipality will have to develop its unique plans of action.

\section{Case Study 3: Rain-fed (dryland) agriculture, including livestock activities}

Adaptation in South Africa's rain-fed, i.e. dryland, agriculture sector covers the range from small-scale subsistence to emerging to large-scale commercial farming and includes intensive and extensive livestock rearing as well as commercial production forestry. Similarly, the range covers farming for export as well as for internal consumption, farming for local and for national food security, and farming within climates which range from semi-arid to sub-humid and from the winter rainfall areas through the all-year to the summer rainfall areas.

The emphasis in this paper (Table 5) is on water-related adaptation in the dryland agriculture sector. When it comes to adapting through water storage, the emphasis here is on 
Table 5

Adaptation recommendations for dryland agriculture, including livestock activities

\section{ENHANCING ADAPTIVE CAPACITY}

ADAPTING TO CHANGES

CROSS REFERENCES TO

TECHNOLOGICAL AND STRUCTURAL

IN...
SCHULZE (2011)

- Storage and reticulation

- Surface water

- Small reservoirs

- Flash floods

Enhanced evaporation

DDF - Rainfall: Short

DDF - Streamflows

DDF - Peak discharge

Threshold streamflows

Water temperature

Water quality - Sed

Water quality - Chem

Water quality - Biol

Agricultural droughts

Hydrological droughts

Surface water supply

Groundwater

- Borehole drilling

- Sand dams

- Rainwater harvesting

- Flood / storm surge control

- Structures (e.g. dams, spillways, stormwater systems, levees, wave breaks, vegetation)

- Early warning systems

- Near real-time (hours to days)

- Short-term (days to weeks)

- Medium-term (month to season)

- Long-term (years to decades)

- Communication of forecasts to end users

- Indigenous coping strategies

- Precipitation enhancement
- Hydrological drought Agricultural drought Groundwater recharge

- Flash floods Hydrological droughts Groundwater supply Enhanced evaporation Threshold streamflows

- Hydrological droughts Agricultural droughts Threshold rainfalls Surface water supply Groundwater recharge

- Flash floods Regional floods Sea-level rise Storm surges

- Flash floods Regional floods Soil moisture Threshold rainfalls Threshold streamflows

- Regional floods Hydrological droughts Agricultural droughts Heat waves Threshold rainfalls Threshold streamflows

- Hydrological droughts Agricultural droughts Groundwater recharge

- Hydrological droughts Surface water supply Groundwater recharge

- Flash floods

Regional floods Agricultural droughts Heat waves Threshold rainfalls Soil moisture Storm surges

- Flash floods Regional floods Agricultural droughts - Agricultural droughts Surface water supply Hydrological droughts
Ch 5.6, 7.1

Ch 4.1, 4.2, 8.1

Ch 7.1

Ch 7.3

Ch 5.6

Ch 5.5

See Barichievy et al. (2010a)

Ch 5.7

Ch 8.3

Not in report

Ch 4.2, 6.1, 6.2, 8.2

Ch 5.5, 6.1, 6.2, 8.1, 8.2

Ch 5.2, 5.4, 6.1, 6.2, 8.1, 8.4

Ch $5.5,6.1,6.2,8.1,8.2$

Ch $4.2,6.1,6.2,8.2$

Ch 5.3

Ch 5.6, 7.1

Ch 5.5, 6.1, 6.2, 8.1, 8.2

Not in report

Ch 4.1, 4.2, 8.1

Ch 5.5

Ch 5.5, 6.1, 6.2, 8.1, 8.2

Ch $4.2,6.1,6.2,8.2$

Ch 3.6

Ch 5.2, 5.4, 6.1, 6.2, 8.1, 8.4

Ch 5.3

Ch 5.6, 7.1

Ch 7.2, 7.3

Not in report

Not in report

Ch 5.6, 7.1

Ch 7.2, 7.3

Ch 4.2

Ch 3.6

Ch 5.5

Ch 7.2, 7.3

Ch 5.5, 6.1, 6.2, 8.1, 8.2

Ch 4.2, 6.1, 6.2, 8.2

See Schulze and Kunz (2010)

Ch 3.6

Ch 5.5

Ch 5.5, 6.1, 6.2, 8.1, 8.2

Ch 4.2, 6.1, 6.2, 8.2

Ch 5.2, 5.4, 6.1, 6.2, 8.1, 8.4

Ch 5.3

Ch 5.5, 6.1, 6.2, 8.1, 8.2

Ch 5.2, 5.4, 6.1, 6.2, 8.1, 8.4

Ch 5.3

Ch 5.6, 7.1

Ch 7.2, 7.3

Ch $5.5,6.1,6.2,8.1,8.2$

Ch 4.2, 6.1, 6.2, 8.2

See Schulze and Kunz (2010)

Ch 3.6

Ch 4.2

Not in report

Ch 5.6, 7.1

Ch $7.2,7.3$

Ch $4.2,6.1,6.2,8.2$

Ch $4.2,6.1,6.2,8.2$ 


\begin{tabular}{|c|c|c|}
\hline \multicolumn{3}{|c|}{ Table 5 (continued) } \\
\hline KNOWLEDGE / SKILLS / PARTICIPATION & $\begin{array}{c}\text { ADAPTING TO CHANGES } \\
\text { IN . . . }\end{array}$ & CROSS REFERENCES \\
\hline $\begin{array}{l}\text { - Research and development } \\
\text { - Efficient technologies } \\
\text { - Upgrading of climate models } \\
\text { o Fine-scale information provision relevant to local water } \\
\text { managers } \\
\text { - Improvement of forecast skill / dissemination } \\
\text { - Development of drought-resistant crops } \\
\text { - Communication, training, dissemination } \\
\text { - Awareness creation at operational level } \\
\text { - Training at local level } \\
\text { - Creation of ongoing learning and communication platforms }\end{array}$ & $\begin{array}{l}\text { - Agricultural droughts } \\
\text { Regional floods } \\
\text { - Agricultural droughts } \\
\text { DDF - Rainfall: Short } \\
\text { Heat waves } \\
\text { - Agricultural droughts } \\
\text { Regional floods } \\
\text { Heat waves } \\
\text { Soil moisture } \\
\text { Threshold rainfalls } \\
\text { - Agricultural droughts } \\
\text { Heat waves } \\
\text { Soil moisture } \\
\text { - Agricultural droughts } \\
\text { Regional floods } \\
\text { Heat waves } \\
\text { Soil moisture } \\
\text { - Agricultural droughts } \\
\text { Regional floods } \\
\text { Heat waves } \\
\text { Soil moisture } \\
\\
\text { - Agricultural droughts } \\
\text { Regional floods } \\
\text { Heat waves } \\
\text { Soil moisture }\end{array}$ & $\begin{array}{l}\text { Ch } 4.2,6.1,6.2,8.2 \\
\text { Ch 7.2, 7.3 } \\
\text { Ch } 4.2,6.1,6.2,8.2 \\
\text { Ch 7.1 } \\
\text { See Schulze and Kunz (2010) } \\
\text { Ch 4.2, 6.1, 6.2, 8.2 } \\
\text { Ch 7.2, 7.3 } \\
\text { See Schulze and Kunz (2010) } \\
\text { Ch 4.2 } \\
\text { Ch 3.6 } \\
\text { Ch 4.2, 6.1, 6.2, 8.2 } \\
\text { See Schulze and Kunz (2010) } \\
\text { Ch 4.2 } \\
\text { Ch 4.2, 6.1, 6.2, 8.2 } \\
\text { Ch 7.2, 7.3 } \\
\text { See Schulze and Kunz (2010) } \\
\text { Ch 4.2 } \\
\text { Ch 4.2, 6.1, 6.2, 8.2 } \\
\text { Ch 7.2, 7.3 } \\
\text { See Schulze and Kunz (2010) } \\
\text { Ch 4.2 } \\
\text { Ch 4.2, 6.1, 6.2, 8.2 } \\
\text { Ch 7.2, 7.3 } \\
\text { See Schulze and Kunz (2010) } \\
\text { Ch 4.2 }\end{array}$ \\
\hline POLICY INSTRUMENTS & $\begin{array}{c}\text { ADAPTING TO CHANGES } \\
\text { IN . . }\end{array}$ & CROSS REFERENCES \\
\hline $\begin{array}{l}\text { - International trade } \\
\text { - Other national strategies } \\
\text { - National Environmental Management Plan } \\
\text { - Conservation of Agricultural Resources Act }\end{array}$ & $\begin{array}{l}\text { - Agricultural droughts } \\
\text { - All } \\
\text { - All }\end{array}$ & Ch $4.2,6.1,6.2,8.2$ \\
\hline RISK SHARING / SPREADING & $\begin{array}{c}\text { ADAPTING TO CHANGES } \\
\text { IN . . . }\end{array}$ & CROSS REFERENCES \\
\hline $\begin{array}{l}\text { - Private sector strategies } \\
\text { - Insurance } \\
\circ \text { Primary insurers } \\
\circ \text { Micro-insurance } \\
\text { - Banks } \\
\circ \text { Private } \\
\\
\circ \text { Micro-lenders }\end{array}$ & $\begin{array}{l}\text { - Agricultural droughts } \\
\text { Hydrological droughts } \\
\text { Regional floods } \\
\text { Flash floods } \\
\text { - Flash floods } \\
\text { Regional floods } \\
\text { Agricultural droughts } \\
\\
\text { - Agricultural droughts } \\
\text { DDF - Rainfall: Short } \\
\text { DDF - Streamflows } \\
\text { DDF - Peak discharge } \\
\text { Heat waves } \\
\text { Regional floods } \\
\text { Flash floods } \\
\text { - Agricultural droughts } \\
\text { Flash floods } \\
\text { Regional floods }\end{array}$ & $\begin{array}{l}\text { Ch } 4.2,6.1,6.2,8.2 \\
\text { Ch } 5.5,6.1,6.2,8.1,8.2 \\
\text { Ch } 7.2,7.3 \\
\text { Ch } 5.6,7.1 \\
\text { Ch } 5.6,7.1 \\
\text { Ch } 7.2,7.3 \\
\text { Ch } 4.2,6.1,6.2,8.2 \\
\\
\text { Ch } 4.2,6.1,6.2,8.2 \\
\text { Ch } 7.1 \\
\text { Ch } 7.3 \\
\text { Ch } 5.6 \\
\text { See Schulze and Kunz (2010) } \\
\text { Ch } 7.2,7.3 \\
\text { Ch } 5.6,7.1 \\
\text { Ch } 4.2,6.1,6.2,8.2 \\
\text { Ch } 5.6,7.1 \\
\text { Ch } 7.2,7.3\end{array}$ \\
\hline
\end{tabular}

small reservoirs, the utilisation of subterranean waters through boreholes and sand dams as well as rainwater harvesting, all depending on the type of farming practised and where it is being carried out. The application of early warning systems across the range of lead times is an excellent adaptation strategy because they determine a number of in-field and planning operations for farmers. However, for farmers a knowledge of not only when it is going to rain but also when and how often heat waves are projected to occur also becomes important. Indigenous coping strategies built on generations of experiences play an important role for all farmers, while for some precipitation enhancement becomes an option, not only to induce rainfall, but also as a hail suppressant. Under the knowledge/skills/participation category the development of 
- Land-use measures

- Conservation structures

- Adaptive spatial planning

- Tillage practices

- Use of organic (instead of chemical) fertilisers

- Alien invasive clearing activities

- Crop change

- Resettlement
IN

\begin{tabular}{l|l} 
- DDF - Rainfall: Short & Ch 7.1 \\
DDF - Streamflows & Ch 7.3 \\
DDF - Peak discharge & Ch 5.6 \\
Flash floods & Ch $5.6,7.1$ \\
Regional floods & Ch $7.2,7.3$ \\
Storm surges & Not in Report \\
Agricultural droughts & Ch $4.2,6.1,6.2,8.2$ \\
- Flash floods & Ch $5.6,7.1$ \\
Regional floods & Ch $7.2,7.3$ \\
Water quality - Seds & Ch 5.7 \\
Water quality - Chem & Ch 8.3 \\
Sea-level rise & Not in Report \\
Storm surges & Not in Report \\
Agricultural droughts & Ch $4.2,6.1,6.2,8.2$ \\
Heat waves & See Schulze and Kunz (2010) \\
Thresholds - Rainfall & Ch 3.6 \\
Soil moisture & Ch 4.2 \\
Soil moisture & Ch 4.2 \\
Agricultural droughts & Ch $4.2,6.1,6.2,8.2$ \\
- Surface water supply & Ch $5.2,5.4,6.1,6.2,8.1,8.4$ \\
- Heat waves & See Schulze and Kunz (2010) \\
Threshold rainfalls & Ch 3.6 \\
Agricultural droughts & Ch $4.2,6.1,6.2,8.2$ \\
Threshold rainfalls & Ch 3.6 \\
Soil moisture & Ch 4.2 \\
Agricultural droughts & Ch $4.2,6.1,6.2,8.2$ \\
Regional floods & Ch $7.2,7.3$ \\
\hline
\end{tabular}

This industry covers the entire range of insurers from primary insurers through the re-insurers (for projected changes in major hydro-climatic disasters) and micro-insurers, and would promote conservation structures as a preventative strategy.

\section{Case Study 5: Aquatic ecosystems (e.g. estuaries, wetlands, buffers and environmental flows)}

As in the case of municipalities (Case Study 2) and of agriculture (Case Study 3), when assessing the adaptation options for aquatic ecosystems, one could readily look at subcategorising these and in this instance evaluate each of wetlands, estuaries and environmental flows separately. Commonalities regarding adaptation options when factoring in climate change nevertheless exist. The impacts of especially large upstream reservoirs, but also the combined effects of large numbers of small dams upstream, can have major repercussions on downstream wetlands and estuary functioning and on environmental flow requirements by altering magnitudes, frequencies, durations, timing and rates of flows (Table 7). Controlled reservoir releases to compensate for these changes would have to be re-assessed in light of new flow regimes. Furthermore, since mimicking natural flow sequences through environmental flow releases from dams can be controlled, this could be enabled by consideration of early warning systems across the range of lead times.

Policy instruments to back up and implement environmental flow requirements and effective wetland and estuary management under changed conditions include national water (and other) master plans as well as provincial and local strategies and plans of action, while consideration of adaptive spatial planning, conservation structures and clearing of alien invasive plants all affect wetlands and estuarine functioning as well as flows to mimic natural conditions. rainfall and design floods) and hence the re-delimitation of flood lines in the light of climate change findings. 


\begin{tabular}{|c|c|c|}
\hline \multicolumn{3}{|c|}{$\begin{array}{l}\text { Table } 6 \\
\text { Adaptation recommendations for the insurance industry from a hydro-climatic perspective }\end{array}$} \\
\hline $\begin{array}{l}\text { ENHANCING ADAPTIVE CAPACITY } \\
\text { TECHNOLOGICAL AND STRUCTURAL }\end{array}$ & $\begin{array}{l}\text { ADAPTING TO CHANGES } \\
\text { IN . . . }\end{array}$ & \\
\hline $\begin{array}{l}\text { - Early warning systems } \\
\text { - Near real-time (hours to days) } \\
\text { - Short-term (days to weeks) } \\
\text { - Medium-term (month to season) } \\
\text { - Long-term (years to decades) } \\
\end{array}$ & $\begin{array}{l}\text { - Flash floods } \\
\text { Regional floods } \\
\text { DDF - Rainfall: Short } \\
\text { DDF - Streamflows } \\
\text { DDF - Peak discharge } \\
\text { Heat waves } \\
\text { Threshold rainfalls } \\
\text { Threshold streamflows } \\
\text { - Regional floods } \\
\text { Agricultural droughts } \\
\text { DDF - Rainfall: Long } \\
\text { DDF - Streamflows } \\
\text { DDF - Peak discharge } \\
\text { Heat waves } \\
\text { Threshold rainfalls } \\
\text { Threshold streamflows } \\
\text { - Agricultural droughts } \\
\text { - Regional floods } \\
\text { - Flash floods } \\
\text { Threshold rainfalls } \\
\text { Threshold streamflows } \\
\text { Heat waves } \\
\text { DDF - Rainfall: Short } \\
\text { DDF - Rainfall: Long } \\
\text { DDF - Peak discharge } \\
\text { Regional floods } \\
\text { Hydrological droughts } \\
\text { Agricultural droughts } \\
\text { - Agricultural droughts } \\
\text { - Agricultural droughts } \\
\text { Hydrological droughts }\end{array}$ & $\begin{array}{l}\text { Ch } 5.6,7.1 \\
\text { Ch } 7.2,7.3 \\
\text { Ch } 7.1 \\
\text { Ch } 7.3 \\
\text { Ch } 5.6 \\
\text { See Schulze and Kunz (2010) } \\
\text { Ch } 3.6 \\
\text { Ch } 5.5 \\
\text { Ch } 7.2,7.3 \\
\text { Ch } 4.2,6.1,6.2,8.2 \\
\text { Ch } 7.2 \\
\text { Ch } 7.3 \\
\text { Ch } 5.6 \\
\text { See Schulze and Kunz (2010) } \\
\text { Ch } 3.6 \\
\text { Ch } 5.5 \\
\text { Ch } 4.2,6.1,6.2,8.2 \\
\text { Ch } 7.2,7.3 \\
\text { Ch } 5.6,7.1 \\
\text { Ch } 3.6 \\
\text { Ch } 5.5 \\
\text { See Schulze and Kunz (2010) } \\
\text { Ch } 7.1 \\
\text { Ch } 7.2 \\
\text { Ch } 5.6 \\
\text { Ch } 7.2,7.3 \\
\text { Ch } 5.5,6.1,6.2,8.1,8.2 \\
\text { Ch } 4.2,6.1,6.2,8.2 \\
\text { Ch } 4.2,6.1,6.2,8.2 \\
\text { Ch } 4.2,6.1,6.2,8.2 \\
\text { Ch } 5.5,6.1,6.2,8.1,8.2\end{array}$ \\
\hline KNOWLEDGE / SKILLS / PARTICIPATION & \multicolumn{2}{|l|}{$\begin{array}{l}\text { ADAPTING TO CHANGES } \\
\text { IN ... }\end{array}$} \\
\hline $\begin{array}{l}\text { - Research and development } \\
\text { - Efficient technologies } \\
\text { - Upgrading climate models } \\
\text { o Fine-scale information provision relevant to local water } \\
\text { managers } \\
\text { - Improvement of forecast skill / dissemination } \\
\text { - Development of risk maps / flood lines } \\
\text { - Communication. training, dissemination } \\
\text { - Awareness creation at higher decision-making level }\end{array}$ & $\begin{array}{l}\text { - All } \\
\text { - All } \\
\text { - All } \\
\text { - Flash floods } \\
\text { Regional floods } \\
\text { DDF - Rainfall: Short } \\
\text { DDF - Rainfall: Long } \\
\text { DDF - Streamflows } \\
\text { DDF - Peak discharge } \\
\text { Hydrological droughts } \\
\text { Sea-level rise } \\
\text { Storm surges } \\
\\
\text { - Flash floods } \\
\text { Regional floods } \\
\text { DDF - Rainfall: Short } \\
\text { DDF - Rainfall: Long } \\
\text { DDF - Streamflows } \\
\text { DDF - Peak discharge } \\
\text { Hydrological droughts } \\
\text { Agricultural droughts } \\
\text { Heat waves }\end{array}$ & $\begin{array}{l}\text { Ch } 5.6,7.1 \\
\text { Ch } 7.2,7.3 \\
\text { Ch } 7.1 \\
\text { Ch } 7.2 \\
\text { Ch } 7.3 \\
\text { Ch } 5.6 \\
\text { Ch } 5.5,6.1,6.2,8.1,8.2 \\
\text { Not in report } \\
\text { Not in report } \\
\text { Ch } 5.6,7.1 \\
\text { Ch } 7.2,7.3 \\
\text { Ch } 7.1 \\
\text { Ch } 7.2 \\
\text { Ch } 7.3 \\
\text { Ch } 5.6 \\
\text { Ch } 5.5,6.1,6.2,8.1,8.2 \\
\text { Ch } 4.2,6.1,6.2,8.2 \\
\text { See Schulze and Kunz (2010) }\end{array}$ \\
\hline POLICY INSTRUMENTS & $\begin{array}{l}\text { ADAPTING TO CHANG } \\
\text { IN ... }\end{array}$ & \\
\hline - Disaster management policies / plans & - All & \\
\hline
\end{tabular}




\begin{tabular}{|c|c|c|}
\hline \multicolumn{3}{|c|}{ Table 6 (continued) } \\
\hline RISK SHARING / SPREADING & \multicolumn{2}{|c|}{$\begin{array}{c}\text { ADAPTING TO CHANGES } \\
\text { IN . . . }\end{array}$} \\
\hline $\begin{array}{l}\text { - Private sector strategies } \\
\text { - Insurance } \\
\circ \text { Primary insurers } \\
\circ \text { Re-insurance } \\
\\
\circ \text { Micro-insurance }\end{array}$ & $\begin{array}{l}\text { - Agricultural droughts } \\
\text { Hydrological droughts } \\
\text { DDF - Rainfall: Short } \\
\text { DDF - Rainfall: Long } \\
\text { DDF - Streamflows } \\
\text { DDF - Peak discharge } \\
\text { flash floods } \\
\text { Regional floods } \\
\text { Agricultural droughts } \\
\text { Hydrological droughts } \\
\text { Flash floods } \\
\text { Regional floods } \\
\text { DDF - Rainfall: Short } \\
\text { DDF - Rainfall: Long } \\
\text { DDF - Streamflows } \\
\text { DDF - Peak discharge } \\
\text { Flash floods } \\
\text { Regional floods } \\
\text { Agricultural droughts }\end{array}$ & $\begin{array}{l}\text { Ch } 4.2,6.1,6.2,8.2 \\
\text { Ch } 5.5,6.1,6.2,8.1,8.2 \\
\text { Ch } 7.1 \\
\text { Ch } 7.2 \\
\text { Ch } 7.3 \\
\text { Ch } 5.6 \\
\text { Ch } 5.6,7.1 \\
\text { Ch } 7.2,7.3 \\
\text { Ch } 4.2,6.1,6.2,8.2 \\
\text { Ch } 5.5,6.1,6.2,8.1,8.2 \\
\text { Ch } 5.6,7.1 \\
\text { Ch } 7.2,7.3 \\
\text { Ch } 7.1 \\
\text { Ch } 7.2 \\
\text { Ch } 7.3 \\
\text { Ch } 5.6 \\
\text { Ch } 5.6,7.1 \\
\text { Ch } 7.2,7.3 \\
\text { Ch } 4.2,6.1,6.2,8.2\end{array}$ \\
\hline CHANGE OF USE / ACTIVITY / LOCATION & \multicolumn{2}{|c|}{$\begin{array}{c}\text { ADAPTING TO CHANGES } \\
\text { IN . . }\end{array}$} \\
\hline $\begin{array}{l}\text { - Land-use measures } \\
\text { - Conservation structures }\end{array}$ & $\begin{array}{l}\text { Flash floods } \\
\text { Regional floods } \\
\text { DDF - Rainfall: Short } \\
\text { DDF - Streamflows } \\
\text { DDF - Peak discharge } \\
\text { Storm surges } \\
\text { Agricultural droughts }\end{array}$ & $\begin{array}{l}\text { Ch } 5.6,7.1 \\
\text { Ch } 7.2,7.3 \\
\text { Ch } 7.1 \\
\text { Ch } 7.3 \\
\text { Ch } 5.6 \\
\text { Not in report } \\
\text { Ch } 4.2,6.1,6.2,8.2\end{array}$ \\
\hline
\end{tabular}

\section{Concluding thoughts}

The management of water resources in South Africa under current climatic conditions is already a complex issue, requiring an integrated approach (cf. Fig. 1). Projected changes in climate and resultant changes in the drivers and responses of the hydrological system raise new challenges, be these on the landscape component of the hydrological system or in the channel component or the transitional elements such as floodplains, wetlands or estuaries (cf. Fig. 2). The latest projections (2011), based on simulations using climate outputs from multiple GCMs as inputs to a conceptual-physical hydrological model, show that climate change is not going to be experienced evenly throughout South Africa, with some areas coming out as 'winners', other areas as 'losers' and others still are likely to become real 'hotspots of concern'. Furthermore, climate change does not occur on a 'clean sheet' of virgin catchments not yet impacted upon by human interventions on the land, but will rather be superimposed as an added stressor onto already water-stressed catchments with often complex land uses, often complex water-engineered systems and a strong socio-political as well as economic historical footprint.

The approach taken in this paper has been to develop science-informed strategies and plans of action to adapt to climate change in South Africa's water-related sector through an integrated approach to land and water management as the cornerstone to establishing effective resilience to projected impacts of climate change. Of 17 sectors identified as being vulnerable in some way or other to climate change, the approach of identifying the major categories and subcategories in which adaptive capacity can be enhanced and then identifying the drivers of the hydrological system as well as responses of the hydrological system which are anticipated to change for each category/sub-category, was illustrated by way of a sample of 5 case studies. These were national water-resource planning departments, municipalities, dryland agriculture, the insurance industry and aquatic ecosystems. For each of these five, adaptation options varied widely.

The same approach as above has been adopted for the other 12 sectors identified (Schulze, 2011). Follow-up research within each of the 17 (and more may be identified) sectors is envisaged in the near future, evaluating the respective adaptation table for each and debating/elaborating on its contents. In follow-up workshops the tables would then be amended, expanded and improved upon, hopefully adding further substance and highlighting, on the one hand, the uniqueness of each sector and, on the other hand, the links in adaptive management to other sectors.

Many of the adaptation options listed are, of course, not new and if managed properly and implemented stringently under present climatic conditions would go a long way to adaptation into an unknown and uncertain (not only in climatic terms) future. However, climate change is projected to be associated with added inter-annual and intra-annual variability of rainfall and runoff, with greater hydro-climatic extremes and increases in water temperature, all with wide-ranging ramifications in water-related management sectors. Accounting for, and adapting to, potential effects of climate change in South Africa's water sector are therefore seen as imperatives; indeed, non-consideration of potential effects of climate change and 
Table 7

Adaptation recommendations for aquatic ecosystems

ENHANCING ADAPTIVE CAPACITY

ADAPTING TO CHANGES

CROSS REFERENCES TO TECHNOLOGICAL AND STRUCTURAL IN. SCHULZE (2011)

- Storage and reticulation

- Surface water

- Large reservoirs

- Enhanced evaporation water temperature

Threshold streamflows DDF - Streamflows

DDF - Peak discharge

Water Quality - Seds

Water Quality - Chem

Water Quality - Biol

Regional floods

Hydrological droughts

Surface water supply

Environmental flows

Storm surges

- Small reservoirs

- Surface water supply

Hydrological droughts

DDF - Streamflows

DDF - Peak discharge

Enhanced evaporation

Threshold streamflows

Water temperature

Water quality - Chem

Water quality - Biol

- Groundwater

- Sand dams

- Water reuse / recycling

- Flash floods

Hydrological droughts

- Surface water supply

Water temperature

Water quality - Chem

- Flood / storm surge control

Structures (e.g. dams, spillways, stormwater systems, levees, wave breaks, vegetation)

- Environmental flows

Flash floods

Regional floods

Surface water supply

Sea-level rise

Storm surges

- Early warning systems

- Near real-time (hours to days)

- Environmental flows

Water temperature

Flash floods

Regional floods

Threshold streamflows

DDF - Rainfall: Long

DDF - Streamflows

DDF - Peak discharge

Water quality - Seds

Water quality - Chem

Water quality - Biol

- Short-term (days to weeks)

- Environmental flows

Water temperature

Regional floods

Hydrological droughts

Agricultural droughts

DDF - Rainfall: Long

DDF - Streamflows

DDF - Peak discharge

threshold streamflows

Water Quality - Seds

Water Quality - Chem

Water Quality - Biol

Ch 4.1, 4.2, 8.1

See Barichievy et al. (2010a)

Ch 5.5

Ch 7.3

Ch 5.6

Ch 5.7

Ch 8.3

Not in report

Ch 7.2, 7.3

Ch 5.5, 6.1, 6.2, 8.1, 8.2

Ch 5.2, 5.4, 6.1, 6.2, 8.1, 8.4

See Barichievy et al. (2010b)

Not in report

Ch 5.2, 5.4, 6.1, 6.2, 8.1, 8.4

Ch $5.5,6.1,6.2,8.1,8.2$

Ch 7.3

Ch 5.6

Ch $4.1,4.2,8.1$

Ch 5.5

See Barichievy et al. (2010a)

Ch 8.3

Not in report

Ch 5.6, 7.1

Ch $5.5,6.1,6.2,8.1,8.2$

Ch 5.2, 5.4, 6.1, 6.2, 8.1, 8.4

See Barichievy et al. (2010a)

Ch 8.3

See Barichievy et al. (2010b)

Ch 5.6, 7.1

Ch $7.2,7.3$

Ch 5.2, 5.4, 6.1, 6.2, 8.1, 8.4

Not in Report

Not in Report

See Barichievy et al. (2010b)

See Barichievy et al. (2010a)

Ch 5.6, 7.1

Ch $7.2,7.3$

Ch 5.5

Ch 7.2

Ch 7.3

Ch 5.6

Ch 5.7

Ch 8.3

Not in report

See Barichievy et al. (2010b)

See Barichievy et al. (2010a)

Ch 7.2, 7.3

Ch 5.5, 6.1, 6.2, 8.1, 8.2

Ch 4.2, 6.1, 6.2, 8.2

Ch 7.2

Ch 7.3

Ch 5.6

Ch 5.5

Ch 5.7

Ch 8.3

Not in report 


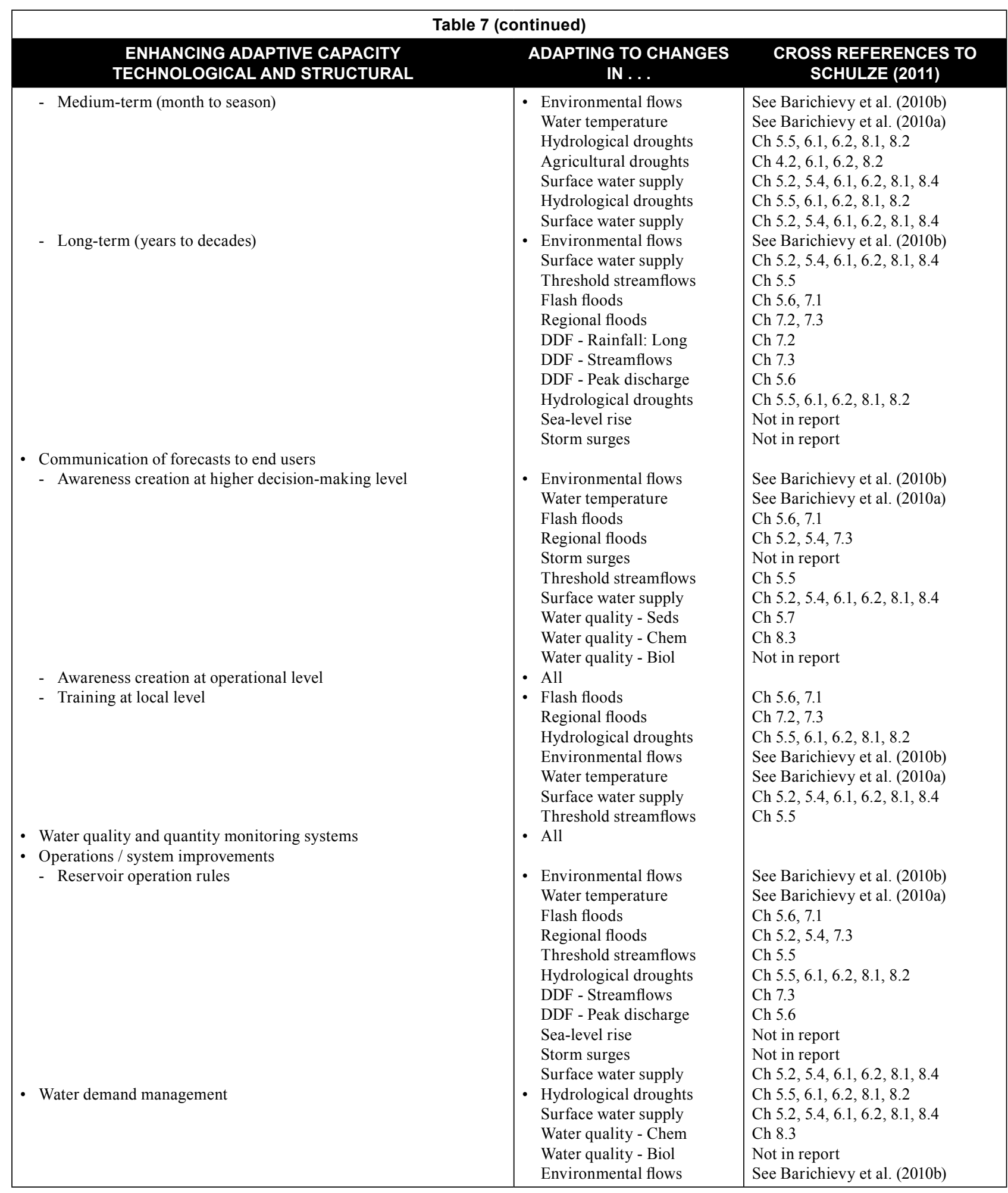

(Table to be continued on next page)

adaptation on the country's water sector could be viewed as an act of omission.

To be really effective, the approaches towards practical management options for climate change, as demonstrated in this paper for selected South African water-related sectors should, of course, be placed within a framework of a climate change adaptation strategy for the country's water sector. While such a strategy should address generic principles, its emphasis should be on the uniquely South African biophysical, socio-economic and institutional situation, and such a strategy would then form the enabling environment within which practical adaptation could be coordinated and implemented.

\section{Acknowledgements}

I wish to thank the Water Research Commission for funding the project titled 'An Evaluation of the Sensitivity of Socio-Economic Activities to Climate Change in Climatically 


\begin{tabular}{|c|c|c|}
\hline \multicolumn{3}{|c|}{ Table 7 (continued) } \\
\hline KNOWLEDGE / SKILLS / PARTICIPATION & $\begin{array}{c}\text { ADAPTING TO CHANGES } \\
\text { IN . . }\end{array}$ & CROSS REFERENCES \\
\hline $\begin{array}{l}\text { - Research and development } \\
\text { - Upgrading of climate models } \\
\text { o Fine-scale information provision relevant to local water } \\
\text { managers } \\
\text { - Improvement of forecast skill / dissemination } \\
\text { - Communication / training / dissemination } \\
\text { - Awareness creation at higher decision-making level } \\
\text { - Awareness creation at operations level (e.g. Senior municipal } \\
\text { officials (re. budget allocation and future special planning) } \\
\text { - Training at middle-management level } \\
\text { - Training at Local Level (e.g. municipal WWT operators) } \\
\text { - Participatory approach in decision-making } \\
\text { - Establishment of inter-departmental learning platforms } \\
\text { - Establishment of integrated communications systems } \\
\text { - Creation of ongoing learning and communication platforms } \\
\text { between main water users }\end{array}$ & $\begin{array}{l}\text { - All } \\
\text { - All } \\
\text { - All } \\
\text { - All } \\
\text { - All } \\
\text { - All } \\
\text { - All } \\
\text { - All } \\
\text { - All }\end{array}$ & \\
\hline POLICY INSTRUMENTS & $\begin{array}{c}\text { ADAPTING TO CHANGES } \\
\text { IN . . }\end{array}$ & CROSS REFERENCES \\
\hline $\begin{array}{l}\text { - International conventions (e.g. RAMSAR) } \\
\text { - International agreements } \\
\text { - National water master plans } \\
\text { - National Water Act of } 1998 \\
\text { - National Water Resource Strategy } \\
\text { - Water for Growth and Development Framework of } 2009 \\
\text { - Catchment management strategies } \\
\text { - River management plans } \\
\text { - Estuary management plans } \\
\text { - Other national strategies } \\
\text { - National Environmental Management Act } \\
\text { - Integrated development plans } \\
\text { - Provincial strategies } \\
\text { - Provincial water reconciliation strategies } \\
\text { - Local Strategies } \\
\text { - Municipal by-laws } \\
\text { - Disaster management policies / plans }\end{array}$ & $\begin{array}{l}\text { - All } \\
\text { - Environmental flows } \\
\text { - Environmental flows } \\
\text { - Environmental flows } \\
\text { - Environmental flows } \\
\text { - Environmental flows } \\
\text { Environmental flows } \\
\text { - Enver temperature } \\
\text { - Environmental flows } \\
\text { - All } \\
\text { - All } \\
\text { - All } \\
\text { - All }\end{array}$ & $\begin{array}{l}\text { See Barichievy et al. (2010b) } \\
\text { See Barichievy et al. (2010b) } \\
\text { See Barichievy et al. (2010b) } \\
\text { See Barichievy et al. (2010b) } \\
\text { See Barichievy et al. (2010b) } \\
\text { See Barichievy et al. (2010b) } \\
\text { See Barichievy et al. (2010a) } \\
\text { See Barichievy et al. (2010b) } \\
\text { See Barichievy et al. (2010b) }\end{array}$ \\
\hline
\end{tabular}

Divergent South African Catchments' (Project No. K5/1843), which provided the platform for the research results presented in this paper. The helpful comments of Ms Nadine Methner of the University of Cape Town are also much appreciated.

\section{References}

APPLETON B, KABAT P, BATES B, HELLMUTH ME, BULLOCK A, CONNOR R, VAN SCHAIK H, VERAART JA, HOFF H, ALCAMO J, SCHULZE RE and DROOGERS P (2003) Climate Changes the Water Rules: How Water Managers can Cope with Today's Climate Variability and Tomorrow's Climate Change. International Dialogue on Water and Climate, Wageningen, The Netherlands. 105 pp.

BARICHIEVY KR, SCHULZE RE and KUNZ RP (2010a) Results 3: Spatial changes in water temperature indicators with climate change in the Thukela catchment using output from the ECHAM/ MPI-OM general circulation model (Chapter 13). In: Schulze RE, Hewitson BC, Barichievy KR, Tadross MA, Kunz RP, Horan MJC and Lumsden TG (eds.) Methodological Approaches to Assessing Eco-Hydrological Responses to Climate Change in South Africa. WRC Report No. 1562/1/10. Water Research Commission, Pretoria, RSA. pp. 147-175.

BARICHIEVY KR, SCHULZE RE and KUNZ RP (2010b) Results 2: Changes in selected eco-hydrological flow indicators over Southern Africa under regimes of climate change as projected by the ECHAM/MPI-OM general circulation model (Chapter 12). In: Schulze RE, Hewitson BC, Barichievy KR, Tadross MA, Kunz RP,
Horan MJC and Lumsden TG (eds.) Methodological Approaches to Assessing Eco-Hydrological Responses to Climate Change in South Africa. WRC Report No. 1562/1/10.Water Research Commission, Pretoria, RSA. 117-146.

BROOKS N and ADGER WN (2005) Assessing and enhancing adaptive capacity. In: Lim B, Spanger-Siegfried E, Burton I, Malone $\mathrm{EL}$ and Huq S (eds.) Adaptation Policy Frameworks for Climate Change. Cambridge University Press, New York, USA. 165-182.

BROOKS N, ADGER WN and KELLY PM (2005) The determinants of vulnerability and adaptive capacity at the national level and the implications for adaptation. Global Environ. Change 15 151-163.

CSAG (CLIMATE SYSTEMS ANALYSIS GROUP) (2008) Downscaled GCMs for different time slices. Report prepared for WRC Research Project No. K5/1843. Climate Systems Analysis Group, University of Cape Town, RSA.

DEA (DEPARTMENT OF ENVIRONMENTAL AFFAIRS, SOUTH AFRICA) (2010) South Africa's Second National Communication under the United Nations Framework Convention on Climate Change. Department of Environmental Affairs, Pretoria, RSA.

DWA (DEPARTMENT OF WATER AFFAIRS, SOUTH AFRICA) (2011) Blue and Green Drop 2011. Department of Water Affairs, Pretoria, RSA. $72 \mathrm{pp}$.

DWAF (DEPARTMENT OF WATER AFFAIRS AND FORESTRY, SOUTH AFRICA) (2004) National Water Resource Strategy ( $1^{\text {st }}$ edn.). September 2004. Department of Water Affairs and Forestry, Pretoria, South Africa..

DWAF (DEPARTMENT OF WATER AFFAIRS AND FORESTRY, SOUTH AFRICA) (2009) Water for Growth and Development 


\begin{tabular}{|c|c|c|}
\hline \multicolumn{3}{|c|}{ Table 7 (continued) } \\
\hline RISK SHARING / SPREADING & $\begin{array}{c}\text { ADAPTING TO CHANGES } \\
\text { IN . . }\end{array}$ & CROSS REFERENCES \\
\hline CHANGE OF USE / ACTIVITY / LOCATION & $\begin{array}{c}\text { ADAPTING TO CHANGES } \\
\text { IN . . }\end{array}$ & CROSS REFERENCES \\
\hline $\begin{array}{l}\text { - Land-use measures } \\
\text { - Conservation structures } \\
\text { - Adaptive spatial planning } \\
\text { - Resettlement } \\
\text { - Maintaining or re-establishment of natural capital (e.g. wetlands, } \\
\text { buffers, etc) }\end{array}$ & $\begin{array}{l}\text { - Flash floods } \\
\text { Regional floods } \\
\text { DDF - Rainfall: Short } \\
\text { DDF - Streamflows } \\
\text { DDF - Peak discharge } \\
\text { Storm surges } \\
\text { - Flash floods } \\
\text { Regional floods } \\
\text { DDF - Rainfall: Short } \\
\text { DDF - Rainfall: Long } \\
\text { DDF - Streamflow } \\
\text { DDF - Peak discharge } \\
\text { Threshold streamflows } \\
\text { Surface water supply } \\
\text { Environmental flows } \\
\text { Sea-level rise } \\
\text { Storm surges } \\
\text { - Surface water supply } \\
\text { - Flash floods } \\
\text { Regional floods } \\
\text { Rainfall thresholds } \\
\text { DDF - Rainfall: Short } \\
\text { DDF - Rainfall: Long } \\
\text { DDF - Streamflows } \\
\text { DDF - Peak discharge } \\
\text { Flash floods } \\
\text { Regional floods } \\
\text { Water quality - Seds } \\
\text { Water quality - Chem } \\
\text { Water quality - Biol }\end{array}$ & 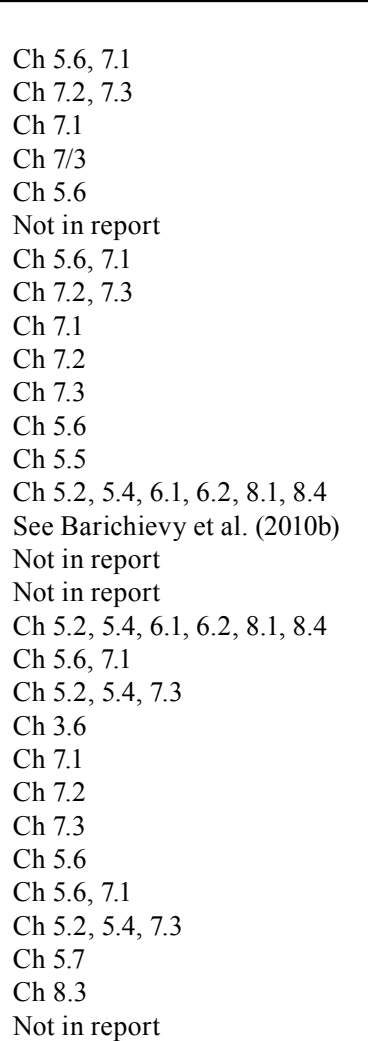 \\
\hline
\end{tabular}

Framework, Version 9. Department of Water Affairs and Forestry, Pretoria, RSA.

HEWITSON BC, TADROSS M and JACK C (2005) Historical precipitation trends over Southern Africa: A climatology perspective (Chapter 18). In: Schulze RE (ed.) Climate Change and Water Resources in Southern Africa: Studies on Scenarios, Impacts, Vulnerabilities and Adaptation. WRC Report No. 1430/1/05. Water Research Commission, Pretoria, RSA. 319-324.

IPCC (2007) Climate change 2007. The physical science basis. In: Solomon S, Quin D, Manning M, Chen, Z, Marquis, M, Averyt, KB, Tignor, M and Miller HL (eds.) Contribution of Working Group I to the Fourth Assessment Report of the Intergovernmental Panel on Climate Change. Cambridge University Press, Cambridge, UK. 996 pp.

KRUGER AC (2006) Observed trends in daily precipitation indices in South Africa: 1910-2004. Int. J.Climatol. 26 2275-2285.

KRUGER AC and SHONGWE S (2004) Temperature trends in South Africa: 1960-2003. Int. J. Climatol. 24 1929-1945.

LUMSDEN TG, KUNZ RP, SCHULZE RE, KNOESEN DM and BARICHIEVY KR (2010) Methods 4: Representation of grid and point scale regional climate change scenarios for national and catchment level hydrological impacts assessments (Chapter 9). In: Schulze RE, Hewitson BC, Barichievy KR, Tadross MA, Kunz RP, Horan MJC and Lumsden TG (eds.) Methodological Approaches to Assessing Eco-Hydrological Responses to Climate Change in South Africa. WRC Report No. 1562/1/10. Water Research Commission, Pretoria, RSA. pp 89-100.

NAKIĆENOVIĆ N, ALCAMO J, DAVIS G, DE VRIES B, FENHANN J, GAFFIN S, GREGORY K, GRÜBLER A, JUNG TY, KRAM T, LA ROVERE EL, MICHAELIS L, MORI S,
MORITA T, PEPPER W, PITCHER H, PRICE L, RAIHI K, ROEHRL A, ROGNER H.-H, SANKOVSKI A, SCHLESINGER M, SHUKLA P, SMITH S, SWART R, VAN ROOIJEN S, VICTOR N and DADI Z (2000) Emissions scenarios. In: Nakićenović N and Swart R (eds.) A Special Report of Working Group III of the Intergovernmental Panel on Climate Change. Cambridge University Press, UK and New York, NY, USA. 599 pp.

NATIONAL WATER ACT (1998) Act No 36 of 1998, Government Gazette No. 19182. Government Printer, Pretoria, RSA. 200 pp.

SCHULZE RE (1995) Hydrology and Agrohydrology: A Text to Accompany the ACRU 3.00 Agrohydrological Modelling System. WRC Report No. TT 69/9/95. Water Research Commission, Pretoria, RSA. 552 pp.

SCHULZE RE (2005a) Adapting to Climate Change in the Water Resources Sector in South Africa (Chapter 27). In: Schulze RE (ed.) Climate Change and Water Resources in Southern Africa: Studies on Scenarios, Impacts, Vulnerabilities and Adaptation. WRC Report No. 1430/1/05. Water Research Commission, Pretoria, RSA. 423-449.

SCHULZE RE (2005b) Selection of a Suitable Agrohydrological Model for Climate Change Impact Studies over Southern Africa. In: Schulze RE (ed.) Climate Change and Water Resources in Southern Africa: Studies on Scenarios, Impacts, Vulnerabilities and Adaptation. Water Research Commission, Pretoria, RSA, WRC Report 1430/1/05. Chapter 7, 95-110.

SCHULZE RE (ed.) (2008) South African Atlas of Climatology and Agrohydrology. WRC Report No. 1489/1/08. Water Research Commission, Pretoria, RSA.

SCHULZE RE (2011) A 2010 Perspective on Climate Change and the South African Water Sector. WRC Report No. 1843/2/11. Water 
Research Commission, Pretoria, RSA.

SCHULZE RE and CHAPMAN RD (2008) Estimation of daily solar radiation over South Africa (Section 5.2). In: Schulze RE (ed.) South African Atlas of Climatology and Agrohydrology. WRC Report No. 1489/1/08. Water Research Commission, Pretoria, RSA.

SCHULZE RE and HORAN MJC (2010) Methods 1: Delineation of South Africa, Lesotho and Swaziland into quinary catchments (Chapter 6). In: Schulze RE, Hewitson BC, Barichievy KR, Tadross MA, Kunz RP, Horan MJC and Lumsden TG (eds.) Methodological Approaches to Assessing Eco-Hydrological Responses to Climate Change in South Africa. WRC Report No. 1562/1/10. Water Research Commission, Pretoria, RSA. 55-62.

SCHULZE RE and KUNZ RP (2010) Climate change 2010 and heat waves (Chapter 3.4). In: Schulze RE (ed.) Atlas of Climate Change and the South African Agricultural Sector: A 2010 Perspective. Department of Agriculture, Forestry and Fisheries, Pretoria, RSA. 73-78.

SCHULZE RE, MAHARAJ M and MOULT N (2008) Reference crop evaporation by the Penman-Monteith method (Section 13.3). In: Schulze RE (ed.). South African Atlas of Climatology and Agrohydrology. WRC Report No. 1489/1/08. Water Research Commission, Pretoria, RSA.

THEESFELD I, SCHMIDT O, SCHEUMANN W, HERRFAHRDTPÄHLE E and IFEJIKA SPERANZA C (2011) Adapting agricultural water governance to climate change: experience from Germany, Spain and California. Discussion Paper, 6/2011. German Development Institute, Bonn, Germany. 45 pp.

UNFCCC (UNITED NATIONS FRAMEWORK CONVENTION ON CLIMATE CHANGE) (2007) Climate Change: Impacts,
Vulnerabilities, and Adaptation in Developing Countries. United Nations Framework Convention on Climate Change, Bonn, Germany.

WARBURTON ML and SCHULZE RE (2005) On the Southern African rainfall station network and its data for climate change detection and other hydrological studies (Chapter 20). In: Schulze RE (ed.) Climate Change and Water Resources in Southern Africa: Studies on Scenarios, Impacts, Vulnerabilities and Adaptation. WRC Report No. 1430/1/05. Water Research Commission, Pretoria, RSA. 339-348.

WARBURTON ML, SCHULZE RE and MAHARAJ M (2005) Is South Africa's temperature changing? An analysis of trends from daily records, $1950-2000$ (Chapter 16). In: Schulze RE (ed.) Climate Change and Water Resources in Southern Africa: Studies on Scenarios, Impacts, Vulnerabilities and Adaptation. WRC Report No. 1430/1/05. Water Research Commission, Pretoria, RSA. 275-295.

WATER SERVICES ACT (1997) Act No. 108 of 1997. Government Gazette No. 18522. Government Printer, Pretoria, RSA.

WHITMORE JS (1971) South Africa's water budget. S. Afr. J. Sci. 67 166-176.

YOHE G and TOL RSJ (2002) Indicators for social and economic coping capacity - moving toward a working definition of adaptive capacity. Global Environ. Change 12 25-40.

ZIERVOGEL G, NYONG A, OSMAN B, CONDE C, CORTÉS S and DOWNING T (2006) Climate Variability and Change: Implications for Household Food Security. AIACC Working Paper No. 20, International START Secretariat, Washington DC, USA. 34 pp. 
